Article

\title{
Rapid Transcriptional Reprogramming Triggered by Alteration of the Carbon/Nitrogen Balance Has an Impact on Energy Metabolism in Nostoc sp. PCC 7120
}

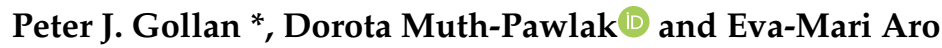 \\ Department of Biochemistry, Molecular Plant Biology, University of Turku, Tykistökatu 6A, \\ 20520 Turku, Finland; dokrmu@utu.fi (D.M.-P.); evaaro@utu.fi (E.-M.A.) \\ * Correspondence: petgol@utu.fi
}

Received: 29 October 2020; Accepted: 18 November 2020; Published: 20 November 2020

check for updates

\begin{abstract}
Nostoc (Anabaena) sp. PCC 7120 is a filamentous cyanobacterial species that fixes $\mathrm{N}_{2}$ to nitrogenous compounds using specialised heterocyst cells. Changes in the intracellular ratio of carbon to nitrogen ( $\mathrm{C} / \mathrm{N}$ balance) is known to trigger major transcriptional reprogramming of the cell, including initiating the differentiation of vegetative cells to heterocysts. Substantial transcriptional analysis has been performed on Nostoc sp. PCC 7120 during N stepdown (low to high C/N), but not during $\mathrm{C}$ stepdown (high to low $\mathrm{C} / \mathrm{N}$ ). In the current study, we shifted the metabolic balance of Nostoc sp. PCC 7120 cultures grown at $3 \% \mathrm{CO}_{2}$ by introducing them to atmospheric conditions containing $0.04 \% \mathrm{CO}_{2}$ for $1 \mathrm{~h}$, after which the changes in gene expression were measured using RNAseq transcriptomics. This analysis revealed strong upregulation of carbon uptake, while nitrogen uptake and metabolism and early stages of heterocyst development were downregulated in response to the shift to low $\mathrm{CO}_{2}$. Furthermore, gene expression changes revealed a decrease in photosynthetic electron transport and increased photoprotection and reactive oxygen metabolism, as well a decrease in iron uptake and metabolism. Differential gene expression was largely attributed to change in the abundances of the metabolites 2-phosphoglycolate and 2-oxoglutarate, which signal a rapid shift from fluent photoassimilation to glycolytic metabolism of carbon after transition to low $\mathrm{CO}_{2}$. This work shows that the $\mathrm{C} / \mathrm{N}$ balance in Nostoc sp. PCC 7120 rapidly adjusts the metabolic strategy through transcriptional reprogramming, enabling survival in the fluctuating environment.
\end{abstract}

Keywords: cyanobacteria; Nostoc sp. PCC 7120; transcriptomics; photosynthesis; carbon/nitrogen

\section{Introduction}

Cyanobacteria use light energy to fix inorganic carbon $\left(C_{i}\right)$ and nitrogen $(N)$, harvested from their aquatic environment, into the metabolic components required for growth and propagation. Environmental sources of $\mathrm{C}_{\mathrm{i}}$ include dissolved $\mathrm{CO}_{2}$ and bicarbonate $\left(\mathrm{HCO}_{3}{ }^{-}\right)$, while $\mathrm{N}$ can be supplied by nitrate $\left(\mathrm{NO}_{3}{ }^{-}\right)$, nitrite $\left(\mathrm{NO}_{2}^{-}\right)$, ammonium $\left(\mathrm{NH}_{4}{ }^{+}\right)$, urea or $\mathrm{N}_{2}$ (in diazotrophic cyanobacteria; reviewed in [1]). The tight coupling of the concentrations of $\mathrm{C}_{\mathrm{i}}$ and $\mathrm{N}$ taken up from the environment prevents metabolic imbalance within the cell, which allows cyanobacteria to thrive amidst varying nutritional conditions. This is achieved in large part by transcriptional modifications that are triggered by fluctuations in the cellular homeostasis of organic carbon (C) and N, which are represented by changes in the relative abundances of key metabolite signals (reviewed in [2-4]). One such metabolite is 2-oxoglutarate (2OG), also known as $\alpha$-ketoglutarate $(\alpha \mathrm{KG})$, which is a product of the tricarboxylic acid (TCA) cycle. The metabolite $2 \mathrm{OG}$ provides the inorganic carbohydrate skeleton for glutamate synthesis that occurs by the incorporation of $\mathrm{NH}_{4}{ }^{+}$in the glutamine synthetase/glutamine-oxoglutarate aminotransferase (GS/GOGAT) cycle. Cellular 2OG levels therefore represent the abundances of both 
$\mathrm{C}$ and $\mathrm{N}$ (reviewed in $[5,6]$ ), making 2OG a central signalling metabolite that triggers transcriptional adjustments to restore $\mathrm{C} / \mathrm{N}$ balance [7-9]. 2-phosphoglycolate (2PG) is another metabolite that controls transcriptional reprogramming in response to $\mathrm{C} / \mathrm{N}$ balance [10], and 2PG is formed when Rubisco catalyses the oxygenation of RuBP (photorespiration), instead of the favoured carboxylation reaction between $\mathrm{RuBP}$ and $\mathrm{CO}_{2}$ (reviewed in $[4,11]$ ). An increase in $2 \mathrm{PG}$ concentration therefore represents $\mathrm{CO}_{2}$ deficiency, triggering transcriptional reprogramming designed to upregulate $\mathrm{C}_{\mathrm{i}}$ import into the cell [12-15].

Nostoc (Anabaena) sp. PCC 7120 is a filamentous, diazotrophic cyanobacterium wherein C/N balance controls the formation of heterocyst cells specialised for fixing $\mathrm{N}_{2}$ into $\mathrm{NH}_{4}{ }^{+}$, while photosynthetic $\mathrm{CO}_{2}$ fixation is restricted to vegetative cells (reviewed in [16,17]). In Nostoc sp. PCC 7120 and other heterocystous cyanobacteria, differentiation in cell structure and function is triggered by changes in $\mathrm{C} / \mathrm{N}$ homeostasis and enacted by massive transcriptional reprogramming [1]. Emphasis on the impact of $\mathrm{N}$ concentration on heterocyst differentiation has revealed the central roles of $2 \mathrm{OG}$ and several regulatory proteins in instigating transcriptional and physiological responses to $\mathrm{N}$ deficit [6]. However, the transcriptional response of heterocystous cyanobacteria to $C_{i}$ availability has drawn only little attention [18], in sharp contrast to that in non-diazotrophic species $[12,13,15,19-22]$. In the current study of the global transcriptome of Nostoc sp. PCC 7120, we found that a shift from $3 \% \mathrm{CO}_{2}$ to $0.04 \%$ $\mathrm{CO}_{2}$ for $1 \mathrm{~h}$ can be largely attributed to changes in the levels of the metabolites 2PG and 2OG, which has a strong effect on genes involved in the import and metabolism of $\mathrm{C}_{\mathrm{i}}$ and $\mathrm{N}$. This study also identified that genes encoding factors involved in photosynthetic electron transport, glycolysis and iron homeostasis are regulated by $\mathrm{C} / \mathrm{N}$ homeostasis, which is suggested to trigger a transition from efficient photoautotrophic growth and energy storage to photoinhibition and glycolysis.

\section{Materials and Methods}

\subsection{Growth and $\mathrm{CO}_{2}$ Stepdown}

Nostoc sp. PCC 7120 cultures were grown in BG11 medium [23] buffered with $10 \mathrm{mM}$ TES-KOH ( $\mathrm{pH}$ 8.0) at $30{ }^{\circ} \mathrm{C}$ under constant illumination of $50 \mu \mathrm{mol}$ photons $\mathrm{m}^{-2} \mathrm{~s}^{-1}$ with $120 \mathrm{rpm}$ agitation, in air enriched with $3 \%(v / v) \mathrm{CO}_{2}$. During the exponential growth phase $\left(\mathrm{OD}_{750}=1.0\right), 2 \mathrm{~mL}$ samples were taken from three individual replicate cultures and frozen for RNA isolation. For $\mathrm{CO}_{2}$ stepdown, the cultures were pelleted and the pellets washed once with fresh BG11, before resuspension in fresh BG11 and growth in air containing $0.04 \%(v / v) \mathrm{CO}_{2}$. After $1 \mathrm{~h}, 2 \mathrm{~mL}$ samples were collected from three replicates and frozen for RNA isolation.

\subsection{RNA Isolation and Transcriptomics}

Total RNA was isolated as described in [24]. Total RNA samples were submitted to the Beijing Genomics Institute (China) for library construction and RNA sequencing using Illumina HiSeq2500. RNA reads were aligned using Strand NGS 2.7 software (Avadis) using the Nostoc sp. PCC 7120 reference genome and annotations downloaded from Ensembl (EBI). Aligned reads were normalised and quantified using the DESeq package (R). Significantly differentially expressed genes were identified using a 2-way ANOVA. $p$-Values were adjusted for false discovery rate (FDR) using the Benjamini-Hochberg procedure.

\section{Results}

The transcriptome of Nostoc sp. PCC 7120 grown in BG11 under 3\% $\mathrm{CO}_{2}$-enriched air was compared with that of the same strain shifted from $3 \% \mathrm{CO}_{2}$ to $0.04 \% \mathrm{CO}_{2}$ for $1 \mathrm{~h}$, revealing 230 genes to be upregulated $>2$-fold and 211 genes to be downregulated $>2$-fold, in the low $\mathrm{CO}_{2}$ condition. The RNAseq data are available at the NCBI Sequence Read Archive (submission SUB8244772). As expected, given the short period under a new metabolic condition, no differences in the growth rates, lengths of filaments or frequencies of heterocysts (approximately $4 \%$ of all cells under $3 \% \mathrm{CO}_{2}$ ) 
were observed between the cultures exposed to $0.04 \% \mathrm{CO}_{2}$ conditions, compared to those grown at $3 \%$ $\mathrm{CO}_{2}$. Therefore, statistical tests of these parameters in the different cultures were not performed.

\subsection{Uptake and Metabolism of Carbon and Nitrogen Are Inversely Responsive to $\mathrm{Low}^{\mathrm{CO}} \mathrm{CO}_{2}$ Conditions}

The operons encoding three plasma membrane-localised $\mathrm{HCO}_{3}{ }^{-}$uptake systems were among the most strongly upregulated entities in Nostoc sp. PCC 7120 following $\mathrm{CO}_{2}$ stepdown (Table 1). In cyanobacteria, the Cmp (BCT1) system is powered by ATP hydrolysis [25], while the SbtA and BicA systems depend on $\mathrm{Na}^{+}$ions for $\mathrm{HCO}_{3}{ }^{-}$symport $[21,26]$. The upregulation of the operon encoding the Mrp $\mathrm{Na}^{+}: \mathrm{H}^{+}$antiporter upon $\mathrm{CO}_{2}$ stepdown may also be linked to $\mathrm{HCO}_{3}{ }^{-}$uptake through the extrusion of $\mathrm{Na}^{+}$to support SbtA and BicA activity $[27,28] . \mathrm{HCO}_{3}{ }^{-}$uptake in cyanobacteria forms a major part of the carbon concentration mechanism (CCM), which also involves the concentration of cellular $\mathrm{CO}_{2}$ into $\mathrm{HCO}_{3}{ }^{-}$by a customised NAD(P)H dehydrogenase (NDH-1) complex [29]. Genes $n d h F 3, n d h D 3$ and cupA, which encode subunits that specialise the NDH1-MS complex for inducible $\mathrm{CO}_{2}$ uptake, were upregulated after $\mathrm{CO}_{2}$ stepdown (Table 1), as were several other genes encoding the core $\mathrm{NDH}-1 \mathrm{M}$ complex (see below). Notably, a putative cupS orthologue (alr1320), which is encoded separately from the $n d h F 3 / n d h D 3 /$ cupA cluster in the Nostoc sp. PCC 7120 genome [30], was not differentially expressed (DE) in the current work. Genes encoding Rubisco and some carboxysome subunits were mildly upregulated in low $\mathrm{CO}_{2}$ (1.3 to 1.7 fold change (FC); not shown), while other CCM components were not $\mathrm{DE}$, suggesting that these components were already in sufficient abundance before $\mathrm{CO}_{2}$ stepdown, whereas $\mathrm{C}_{\mathrm{i}}$ uptake from the environment, especially $\mathrm{HCO}_{3}{ }^{-}$uptake, was apparently a primary concern for survival after $1 \mathrm{~h}$ under low $\mathrm{CO}_{2}$.

The decrease in $\mathrm{CO}_{2}$ was found to cause downregulation of the nir operon, which encodes subunits of an ATP-dependent nitrate $\left(\mathrm{NO}_{3}{ }^{-}\right)$transporter, as well as $\mathrm{NO}_{3}{ }^{-}$and nitrite $\left(\mathrm{NO}_{2}{ }^{-}\right)$reductases $[31,32]$. The nir operon is responsible for $\mathrm{NO}_{3}{ }^{-}$uptake and reduction to ammonia $\left(\mathrm{NH}_{3}\right)$, and is broadly conserved across cyanobacteria (reviewed in [5]). Unlike the nir operon, the majority of nif genes that encode subunits for the assembly and function of nitrogenase, which reduces atmospheric $\mathrm{N}_{2}$ to $\mathrm{NH}_{3}$, were not DE in the current work. Exceptions were nifB and nifH2, which were downregulated (Table 1). A gene that encodes a protein similar to the C-terminus of Mo-like nitrogenase (alr1713) was strongly downregulated, along with its neighbour (asr1714); however, the function of the encoded proteins is not known. Since heterocyst development is upregulated by a high $\mathrm{C} / \mathrm{N}$ ratio (reviewed in [33]), it was not surprising to see many genes involved in the structural development of heterocysts repressed by the shift to low $\mathrm{CO}_{2}$. In particular, the $h p d, h g l$ and $d e v$ gene clusters that encode many components for the synthesis and export of glycolipids, which form the oxygen-impermeable heterocyst envelope (reviewed in $[34,35])$, and were downregulated in the current data. Notably, the hep genes encoding heterocyst outer layer polysaccharides were only moderately downregulated by the shift to low $\mathrm{CO}_{2}$ (average FC -1.5, data not shown).

\subsection{Expression of Genes Encoding Photosynthetic and Respiratory Components Responds to Low $\mathrm{CO}_{2}$ Conditions}

Expression of genes encoding photosystem II (PSII) core proteins D1 and D2 was upregulated after the shift to low $\mathrm{CO}_{2}$ (Table 2), indicating an increase in the damage and turnover of PSII reaction centres [36,37]. In keeping with this, the genes encoding the two FtsH proteases involved in the degradation and turnover of damaged D1 protein were also upregulated $[38,39]$. We also found strongly induced expression of the flv2-flv 4 operon, as well as several genes encoding orange carotenoid proteins (OCPs) and early light-inducible proteins (ELIPs), all of which are associated with PSII photoprotection [40-44]. These expression data suggest that the shift to low $\mathrm{CO}_{2}$ led to the over-reduction, damage and repair of PSII. Given this evidence for PSII over-reduction, it was surprising to find the gene encoding the "plastid" terminal oxidase (PTOX) as one of the most strongly downregulated in the current study (Table 2), being highly expressed under $3 \% \mathrm{CO}_{2}$ and strongly repressed in $0.04 \% \mathrm{CO}_{2}$. PTOX is part of a water-water cycle that moves electrons from reduced 
plastoquinone (PQ) to $\mathrm{O}_{2}$, and is thought to be an electron valve for balancing the photosynthetic redox state [45], which would presumably be important under low $\mathrm{CO}_{2}$ (discussed below).

Virtually all genes encoding subunits of photosystem I (PSI) were substantially downregulated in the current study, which is in contrast to their increased expression in Synechocystis sp. PCC 6803 and unchanged expression Synechococcus elongatus PCC 7942 in low $\mathrm{CO}_{2}[13,20]$. PSI downregulation in Nostoc sp. PCC 7120 points towards a decrease in PSI electron transport that may be related to the diminution of the terminal electron acceptor $\mathrm{CO}_{2}$. These conditions would also be expected to upregulate $\mathrm{O}_{2}$ reduction and the subsequent formation of toxic superoxide radicals $\left(\mathrm{O}_{2}{ }^{\bullet-}\right)$; indeed, genes encoding a superoxide dismutase (SodB; alr2938) and peroxiredoxin (all2375), involved in reactive oxygen species (ROS) scavenging, were upregulated 3.2-fold and 2.3-fold, respectively (not shown). The expression of isiB (alr2405), which encodes a flavodoxin (Fld) that accepts electrons from PSI via a flavin mononucleotide cofactor [46], was also upregulated after low $\mathrm{CO}_{2}$ treatment (Table 2), suggesting a shortage of oxidised ferredoxin (Fd) acceptors [47]. The upregulated expression of genes encoding $\mathrm{F}_{0}-\mathrm{F}_{1}$ ATP synthase points to an increased demand for energy in low $\mathrm{CO}_{2}$, required for $\mathrm{HCO}_{3}{ }^{-}$import and $\mathrm{CO}_{2}$ hydration (reviewed in [2]). Notably, the gene alr1004 encoding an enzyme that converts glyoxylate to glycine for the detoxification of 2PG [18] was found to be downregulated after $\mathrm{CO}_{2}$ stepdown, while other enzymes in the glycolate metabolism pathway were not DE.

Table 1. Differentially Expressed (DE) Genes Involved in Carbon and Nitrogen Metabolism.

\begin{tabular}{|c|c|c|c|c|c|}
\hline Name $^{1}$ & Gene ID $^{1}$ & Description & Process & Fold Change $^{2}$ & $p$-Value $^{3}$ \\
\hline sbt operon & all2133-all2134 & $\begin{array}{c}\mathrm{Na}^{+} \text {-dependent bicarbonate } \\
\text { permease, } \mathrm{P}_{\mathrm{II}} \text {-like regulatory } \\
\text { protein }\end{array}$ & \multirow{3}{*}{$\begin{array}{l}\text { Bicarbonate } \\
\text { import }\end{array}$} & 78.8 & $<0.001$ \\
\hline cmp operon & alr2877-alr 2880 & $\begin{array}{l}\text { ATP-dependent bicarbonate } \\
\text { uptake subunits }\end{array}$ & & 36.4 & $<0.001$ \\
\hline bic $A$ operon & all1303-all1304 & $\begin{array}{l}\mathrm{Na}^{+} \text {-dependent bicarbonate } \\
\text { permease, } \mathrm{Na}^{+}: \mathrm{H}^{+} \text {antiporter }\end{array}$ & & 8.7 & $<0.001$ \\
\hline mrp operon & all1837-all1843 & $\mathrm{Na}^{+}: \mathrm{H}^{+}$antiporter subunits & $\begin{array}{l}\mathrm{Na}^{+} \text {extrusion, } \\
\mathrm{pH} \text { regulation }\end{array}$ & 5.4 & $<0.001$ \\
\hline$n d h F 3$ & alr4156 & NDH-1MS subunit 5 & \multirow[b]{3}{*}{$\mathrm{CO}_{2}$ uptake } & 2.5 & 0.002 \\
\hline$n d h D 3$ & alr4157 & NDH-1MS subunit 4 & & 2.0 & $<0.001$ \\
\hline cupA & alr4158 & $\begin{array}{l}\text { NDH-1MS } \mathrm{CO}_{2} \\
\text { uptake subunit }\end{array}$ & & 5.3 & $<0.001$ \\
\hline nir operon & alr0607-alr0612 & $\begin{array}{c}\text { Nitrate/nitrite reductase, } \\
\text { ATP-dependent } \\
\text { nitrate permease }\end{array}$ & \multirow{2}{*}{$\begin{array}{l}\text { Nitrate/nitrite } \\
\text { import and } \\
\text { metabolism }\end{array}$} & -3.5 & 0.017 \\
\hline nirB & all0605 & $\begin{array}{l}\text { Nitrate-dependent expression } \\
\text { of nir cluster }\end{array}$ & & -2.9 & $<0.001$ \\
\hline nifB & all1517 & $\begin{array}{c}\text { Fe-Mo cofactor } \\
\text { biosynthesis subunit }\end{array}$ & \multirow{4}{*}{$\begin{array}{l}\mathrm{N}_{2} \text { fixation, } \\
\text { heterocyst } \\
\text { development } \\
\text { and function }\end{array}$} & -2.0 & 0.002 \\
\hline nifH2 & alr0874 & $\begin{array}{l}\text { Fe-S cluster-binding } \\
\text { nitrogenase reductase }\end{array}$ & & -3.2 & 0.024 \\
\hline$h g d, h g l$ clusters & all5341-alr5359 & $\begin{array}{l}\text { Heterocyst glycolipid } \\
\text { layer biosynthesis }\end{array}$ & & -2.6 & 0.004 \\
\hline dev operon & alr3710-alr3712 & $\begin{array}{c}\text { ATP-binding subunit, } \\
\text { membrane transport subunits }\end{array}$ & & -2.1 & 0.004 \\
\hline alr1713 & alr1713 & $\begin{array}{l}\text { Similar to Mo-dependent } \\
\text { nitrogenase, C-terminus }\end{array}$ & \multirow[t]{2}{*}{ Unknown } & -5.6 & 0.002 \\
\hline asr1714 & asr1714 & Uncharacterised protein & & -5.8 & $<0.001$ \\
\hline
\end{tabular}

1 Shaded cells represent operons or clusters of neighbouring genes; ${ }^{2}$ Fold changes of genes upregulated or downregulated in low $\mathrm{CO}_{2}$, compared to high $\mathrm{CO}_{2}$, are coloured orange or green, respectively. In cases of multiple genes, average fold changes are shown; ${ }^{3} p$-values determined by moderated $t$-test. In cases of multiple genes, largest $p$-value is shown. 
Table 2. Differentially Expressed (DE) Genes Involved in Photosynthesis and Respiration.

\begin{tabular}{|c|c|c|c|c|c|}
\hline Name ${ }^{1}$ & Gene ID $^{1}$ & Description & Process & Fold Change $^{2}$ & $p$ Value $^{3}$ \\
\hline$p s b A I I$ & alr3727 & Photosystem II D1 protein & \multirow{2}{*}{ PSII electron transport } & 6.9 & $<0.001$ \\
\hline psbAIII & alr4592 & Photosystem II D1 protein & & 1.9 & 0.003 \\
\hline psbAIV & all3572 & Photosystem II D1 protein & \multirow{11}{*}{ PSI electron transport } & 3.7 & $<0.001$ \\
\hline$p s b D$ & alr4548 & Photosystem II D2 protein & & 3.4 & $<0.001$ \\
\hline$p s a A$ & alr5154 & Photosystem I core protein A1 & & -1.9 & 0.035 \\
\hline psaB1 & alr5155 & Photosystem I core protein A2 & & -1.9 & 0.038 \\
\hline psaB2 & alr5314 & Photosystem I core protein A2 & & -2.2 & 0.031 \\
\hline$p s a C$ & asr3463 & Photosystem I Fe-S subunit & & -2.2 & $<0.001$ \\
\hline$p s a D$ & all0329 & Photosystem I reaction centre subunit 2 & & -2.7 & $<0.001$ \\
\hline$p s a E$ & asr4319 & Photosystem I subunit E & & -2.2 & 0.001 \\
\hline psaI & asl3849 & Photosystem I subunit I & & -2.5 & 0.012 \\
\hline pasK & asr4775 & Photosystem I subunit K & & -3.1 & 0.004 \\
\hline psaM & asr4657 & Photosystem I subunit M & & -2.3 & 0.005 \\
\hline flv2 & all4444 & Flavodiiron protein & \multirow{7}{*}{$\begin{array}{c}\text { Other } \\
\text { photosynthetic/respiratory } \\
\text { electron transport }\end{array}$} & 23.7 & $<0.001$ \\
\hline all 4445 & all4445 & Unknown protein & & 31.8 & $<0.001$ \\
\hline flv4 & all4446 & Flavodiiron protein & & 16.7 & $<0.001$ \\
\hline$i s i B$ & alr2405 & Flavodoxin & & 2.9 & 0.003 \\
\hline cyt $A$ & alr4251 & Cytochrome $\mathrm{c}_{6}$ & & -2.2 & 0.011 \\
\hline$f l v 1 B-f l v 3 B$ & all0177-all0178 & Flavodiiron protein (heterocyst-specific) & & -2.0 & 0.004 \\
\hline ptox & all2096 & Alternative plastoquinone oxidase & & -65.0 & $<0.001$ \\
\hline ftsH & alr1261 & FtsH protease & \multirow{2}{*}{ PSII turnover } & 2.3 & $<0.001$ \\
\hline ftsH2 & all3642 & FtsH protease & & 2.4 & $<0.001$ \\
\hline $\begin{array}{c}\text { pec } \\
\text { operon }\end{array}$ & alr0523-alr0527 & Phycoerythrocyanin synthesis & \multirow{8}{*}{$\begin{array}{l}\text { Metabolism/binding of } \\
\text { light-harvesting pigments }\end{array}$} & -3.1 & 0.015 \\
\hline $\begin{array}{c}\text { chlL, } \\
\text { chlN } \\
\text { operon }\end{array}$ & all5076-all5078 & $\begin{array}{l}\text { Protochlorophyllide reductase, } \\
\text { ATP-binding protein }\end{array}$ & & -3.3 & $<0.001$ \\
\hline $\operatorname{chlG}$ & all4480 & Chlorophyll synthase $33 \mathrm{kDa}$ subunit & & 2.2 & 0.003 \\
\hline hemH & alr4616 & Ferrochelatase & & 8.6 & $<0.001$ \\
\hline ocp & all3149 & Orange carotenoid-binding protein & & 23.9 & $<0.001$ \\
\hline ocp-like & all4941 & Orange carotenoid protein-like & & 3.1 & 0.010 \\
\hline asl3726 & asl3726 & CAB/ELIP/HLIP superfamily & & 9.8 & $<0.001$ \\
\hline asr5262 & asr5262 & CAB/ELIP/HLIP superfamily & & 8.6 & 0.005 \\
\hline $\begin{array}{l}\text { atpase } \\
\text { cluster }\end{array}$ & all0004-all0010 & ATP synthase subunits & ATP synthesis & 2.7 & $<0.001$ \\
\hline $\begin{array}{c}n d h-1 \\
\text { operon }\end{array}$ & alr0223-alr0227 & \multirow{4}{*}{ NDH-1 complex subunits } & \multirow{4}{*}{$\begin{array}{l}\text { Electron and } \\
\text { proton transport }\end{array}$} & 2.3 & 0.005 \\
\hline $\begin{array}{c}n d h-1 \\
\text { operon }\end{array}$ & all3840-all3842 & & & 2.1 & 0.001 \\
\hline$n d h B$ & all4883 & & & 2.5 & 0.003 \\
\hline$n d h N$ & alr4216 & & & 1.9 & 0.001 \\
\hline alr1004 & alr1004 & Alanine-glyoxylate transaminase & Glycolate metabolim & -2.7 & $<0.001$ \\
\hline$n d b A$ & all1553 & NDH-2 NAD(P)H:PQ reductase & Respiration & -2.1 & $<0.001$ \\
\hline hupS & all0688 & Uptake hydrogenase, small subunit & \multirow{3}{*}{$\mathrm{H}_{2}$ uptake/evolution } & -2.5 & 0.002 \\
\hline nifJ/PFOR & alr1911 & $\begin{array}{c}\text { Pyruvate-ferredoxin/ } \\
\text { flavodoxin oxidoreductase }\end{array}$ & & -42.4 & $<0.001$ \\
\hline $\begin{array}{c}\text { hox } \\
\text { clusters }\end{array}$ & $\begin{array}{l}\text { alr0750-all0752 } \\
\text { alr0760-alr0766 }\end{array}$ & $\begin{array}{l}\text { Bidirectional hydrogenase subunits, } \\
\text { assembly and regulation }\end{array}$ & & -73.9 & 0.002 \\
\hline$p p s A$ & all0635 & Phophoenolpyruvate synthase & Glycolysis & -107.4 & $<0.001$ \\
\hline
\end{tabular}

${ }^{1}$ Shaded cells represent operons or clusters of neighbouring genes; ${ }^{2}$ Fold changes of genes upregulated or downregulated in low $\mathrm{CO}_{2}$, compared to high $\mathrm{CO}_{2}$, are coloured orange or green, respectively. In cases of multiple genes, average fold changes are shown; ${ }^{3} p$-values determined by moderated $t$-test. In cases of multiple genes, largest $p$-value is shown.

The downregulation of PSI abundance in response to low $\mathrm{CO}_{2}$ can partially clarify the apparent PSII over-reduction discussed above. Lower PSI levels may also be linked to a decrease in the number of heterocysts, which contain a higher PSI:PSII ratio than in vegetative cells [16]. Although such a decrease in heterocysts was not observed after $1 \mathrm{~h}$ in low $\mathrm{CO}_{2}$, suppressed heterocyst development was evident in the downregulation of $h g l$ and $d e v$ clusters (Table 1 ), and this can also explain the suppression of genes encoding cytochrome c6, Flv1B and Flv3B (Table 2) that operate predominately [48] or exclusively [49] in heterocysts. The gene encoding the small subunit of the heterocyst-specific uptake hydrogenase (HupS) was also downregulated here, reflecting the downregulation of the heterocystous nitrogenase activity under low $\mathrm{CO}_{2}$.

We observed downregulation of the pec cluster that encodes the phycoerythrocyanin (PEC) parts of the light-harvesting phycobilisome (PBS) complex [50,51], while genes encoding the other 
components of the PBS were not DE, indicating that the light-harvesting cross-section of PBS in Nostoc sp. PCC 7120 is altered in response to low $\mathrm{CO}_{2}$. An operon encoding a subunit of the light-independent protochlorophyllide reductase (DPOR) was also downregulated after $1 \mathrm{~h}$ in low $\mathrm{CO}_{2}$, while the expression of $\mathrm{chl} G$ and hemH genes, involved in later stages of chlorophyll and haem synthesis, respectively, were upregulated (Table 2).

Most genes encoding subunits of the NDH-1 complex were upregulated under low $\mathrm{CO}_{2}$ (Table 2), probably to fulfil their role in $\mathrm{CO}_{2}$ uptake as part of the NDH-1MS complex described above. In contrast, $n d b A$ encoding NDH-2 was downregulated in the current study, suggesting a decrease in NDH-2-mediated respiration after the shift to low $\mathrm{CO}_{2}$. In addition, the gene encoding phosphoenolpyruvate (PEP) synthase, which converts pyruvate to PEP that is consumed in the TCA cycle, was strongly downregulated (Table 2). Many genes encoding subunits of the bidirectional hydrogenase (Hox) were among the most strongly downregulated in response to low $\mathrm{CO}_{2}$ conditions (Table 2), being both highly expressed in $3 \% \mathrm{CO}_{2}$ and strongly repressed in low $\mathrm{CO}_{2}$. Hox reversibly catalyses the reduction of $\mathrm{H}^{+}$to form $\mathrm{H}_{2}$, powered by reduced $\mathrm{Fd} / \mathrm{Fld}$ with electrons derived from either PSI or pyruvate, the latter route by way of pyruvate ferredoxin/flavodoxin oxidoreductase (PFOR), which converts pyruvate to acetyl-CoA (reviewed in [52]). The nifJ gene encoding PFOR followed a similar expression profile to Hox subunits, being another of the most strongly downregulated genes in the current study. The physiological role of the Hox enzyme is not known, but has been described as an electron valve that can maintain redox balance and store reducing power as $\mathrm{H}_{2}$ during excess photosynthesis or fermentation [52-55]. The expression profile of Hox and PFOR genes suggests that pyruvate-powered hydrogen production is active under $3 \% \mathrm{CO}_{2}$ and inactivated by the shift to low $\mathrm{CO}_{2}$.

\subsection{Expression of Transcription Regulators Responds to Changes in $\mathrm{CO}_{2}$ Conditions}

The current study revealed substantial changes in the expression of several genes encoding transcription regulators, providing evidence of an ongoing cascade of transcriptional reprogramming after $1 \mathrm{~h}$ under low $\mathrm{CO}_{2}$ (Table 3). Upregulated expression of the LysR-type regulator (LTTR) $c m p R$ corresponds to the strong upregulation of its target, the $c m p$ cluster encoding the $\mathrm{BCT} 1 \mathrm{HCO}_{3}{ }^{-}$ transporter (Table 1), as previously shown in Synechocystis sp. PCC 6803, Synechococcus sp. PCC 7942 [56] and Nostoc sp. PCC 7120 [57]. Two sigB-type group 2 sigma factors, which have roles in the transcriptional response to low $\mathrm{CO}_{2}$ and $\mathrm{C} / \mathrm{N}$ balance [58-60], were upregulated after the shift to low $\mathrm{CO}_{2}$ (Table 3). SigB has also been implicated in response to environmental stress and resistance to photoinhibition in Synechocystis sp. PCC 6803 [61,62], which is in line with the upregulation in this study of groES and groEL genes (4.3 to $5.5 \mathrm{FC}$; not shown) and photoprotective factors such as OCPs and the flv2-flv4 operon (Table 2). Two homologous two-component response regulator clusters, which each comprise a histidine kinase and a DNA-binding regulator, were found to be upregulated by low $\mathrm{CO}_{2}$. Of the two, the chromosomal hik31 (C-hik31) operon was more highly upregulated, and has been found to be involved in the responses to oxygen concentration, light and metabolism [63,64]. A TetR-family transcription regulator with unknown function was also upregulated by low $\mathrm{CO}_{2}$ (Table 3).

Another LTTR gene that was highly expressed under high $\mathrm{CO}_{2}$ and was strongly downregulated after low $\mathrm{CO}_{2}$ transition (Table 3) shared substantial sequence homology with the $n d h R$ transcription repressor (also called ccmR) of Synechocystis sp. PCC 6803 [12,27]. In other cyanobacteria, NdhR represses the expression of $\mathrm{CCM}$ genes, including the $s b t$ and $b i c A \mathrm{HCO}_{3}{ }^{-}$importers, the $\operatorname{mrp}$ cluster and the $n d h F 3 / n d h D 3 /$ cupA cluster $[12,15,20,27,65]$. The rapid downregulation of a putative $n d h R$ orthologue in Nostoc sp. PCC 7120 may reveal the mechanism behind the strong upregulation of CCM genes after $\mathrm{CO}_{2}$ stepdown in the current study (Table 1). Downregulation of the transcription enhancer $n t c B$, which increases $\mathrm{N}$ metabolism through upregulation of the nir operon [66], also correlates with downregulation of other N-related genes in the current work (Table 1). Expression of $n t c B$ is controlled by NtcA [1]. As $n t c A$ was not DE in the current study, downregulation of $n t c B$ and other NtcA regulons may be due to the low $\mathrm{CO}_{2}$-induced inactivation of NtcA (discussed below). Similarly, downregulated 
transcriptional regulator genes pat $B$ (also called $c n f R$ ), $\operatorname{devH}$ and $n r r A$ can also be attributed to inhibited NtcA activity [67-71]. These genes are expressed in heterocysts, where PatB upregulates the expression of nifB [72], DevH regulates heterocyst glycolipids [48,68,73] and NrrA induces expression of both the heterocyst regulator het $R$ and fraF encoding a filament integrity protein $[70,74]$. Both nifB and the $h g l$ cluster were downregulated in this study (Table 1), while het $R$ and fraF were not DE (not shown).

Table 3. Differentially Expressed (DE) Genes Encoding Transcription Regulators.

\begin{tabular}{|c|c|c|c|c|c|}
\hline Name & Gene ID & Description & Process & Fold Change $^{1}$ & $p$ Value $^{2}$ \\
\hline cmpR & all0862 & $\begin{array}{l}\text { LysR-type transcriptional } \\
\text { regulator }\end{array}$ & Regulates cmp cluster & 3.1 & $<0.001$ \\
\hline $\operatorname{sig} B$ & all7615 & Group 2 sigma factor & \multirow{2}{*}{ Response to stress } & 4.6 & $<0.001$ \\
\hline sigB3 & all7608 & Group 2 sigma factor & & 3.8 & $<0.001$ \\
\hline C-hik31 operon & all7583-all7584 & Two-component sensor His & \multirow{2}{*}{$\begin{array}{l}\text { Regulation of central metabolism } \\
\text { in response to glucose, low } \mathrm{O}_{2}\end{array}$} & 2.8 & $<0.001$ \\
\hline P-hik31 operon & alr1170-alr1171 & kinase, response regulator & & 1.6 & 0.001 \\
\hline all7523 & all7523 & TetR family regulator & Unknown & 2.4 & 0.046 \\
\hline $\begin{array}{l}\text { putative } n d h R \\
\text { orthologue }\end{array}$ & all4986 & $\begin{array}{c}\text { LysR-type } \\
\text { transcriptional regulator }\end{array}$ & Repression of CCM expression & -146.2 & $<0.001$ \\
\hline$n t c B$ & all0602 & $\begin{array}{c}\text { LysR-type } \\
\text { transcriptional regulator }\end{array}$ & Co-activation of nir operon & -2.4 & 0.002 \\
\hline $\operatorname{dev} H$ & alr3952 & $\begin{array}{c}\text { CRP family } \\
\text { transcriptional regulator }\end{array}$ & Het glycolipid biosynthesis & -2.2 & 0.006 \\
\hline patB/cnfR & all2512 & Heterocyst patterning & \multirow{2}{*}{ Heterocyst development } & -2.4 & 0.001 \\
\hline$n r r A$ & all4312 & OmpR family regulator & & -2.1 & $<0.001$ \\
\hline
\end{tabular}

${ }^{1}$ Fold changes of genes upregulated or downregulated in low $\mathrm{CO}_{2}$, compared to high $\mathrm{CO}_{2}$, are coloured orange or green, respectively. In cases of multiple genes, average fold changes are shown; ${ }^{2} p$-values determined by moderated $t$-test. In cases of multiple genes, largest $p$-value is shown.

\subsection{Low $\mathrm{CO}_{2}$ Conditions Influence the Expression of Metal Homeostasis Genes}

A number of genes and gene clusters related to cellular homeostasis of iron $(\mathrm{Fe})$ and other metals were found to be DE after $\mathrm{CO}_{2}$ stepdown (Table 4). A gene cluster encoding subunits of a periplasmic ferrous $\mathrm{Fe}(\mathrm{Fe}(\mathrm{II}))$ transporter $[75,76]$ was strongly downregulated in the current study (Table 4), indicating a lower uptake of Fe from the environment under low $\mathrm{CO}_{2}$. The suf cluster, encoding proteins involved in Fe mobilization and Fe-S cluster assembly, was also downregulated. The expression of both the Fe(II) transporter and the suf cluster is upregulated by Fe deprivation [77-79], suggesting a surplus of cellular Fe after low $\mathrm{CO}_{2}$ treatment. Several neighbouring clusters of genes encoding subunits of metal cation efflux systems such as copper, nickel, zinc, cadmium and cobalt, were upregulated after low $\mathrm{CO}_{2}$ treatment (Table 4). These genes have been implicated in heavy metal resistance $[80,81]$, although the link to the current conditions is not clear. Taken together, low $\mathrm{CO}_{2}$ appears to induce an active decrease in cellular metal content, which may be a strategy to avoid oxidative stress during the reducing conditions induced by an insufficient availability of photosynthetic electron acceptors.

Table 4. Differentially Expressed (DE) Genes Involved in the Transport and Metabolism of Metals.

\begin{tabular}{|c|c|c|c|c|c|}
\hline Name & Gene ID & Description & Process & Fold Change $^{1}$ & $p$ Value $^{2}$ \\
\hline $\begin{array}{l}\text { Fe(II) transport } \\
\text { operon }\end{array}$ & alr2118-asr 2120 & Ferrous iron transporter subunits & Periplasmic iron import & -42.6 & $<0.001$ \\
\hline suf operon & alr2492-alr2496 & ATPase, iron and sulphur transfer & Fe-S cluster assembly, transfer & -3.8 & $<0.001$ \\
\hline $\begin{array}{l}\text { Metal efflux } \\
\text { cluster }\end{array}$ & all7606-all7611 & Proton extrusion, cation efflux & \multirow{4}{*}{$\begin{array}{l}\text { Metal cation efflux, cellular } \\
\text { metal homeostasis }\end{array}$} & 3.1 & $<0.001$ \\
\hline $\begin{array}{l}\text { Metal efflux } \\
\text { cluster }\end{array}$ & all7616-all7619 & $\begin{array}{l}\text { Cadmium/nickel/zinc/ } \\
\text { cobalt efflux system }\end{array}$ & & 3.9 & $<0.001$ \\
\hline $\begin{array}{l}\text { Metal efflux } \\
\text { cluster }\end{array}$ & all7629-all7633 & $\begin{array}{l}\text { Cadmium/nickel/zinc/ } \\
\text { cobalt efflux system }\end{array}$ & & 5.0 & $<0.001$ \\
\hline $\begin{array}{l}\mathrm{Cu}^{2+} \text { efflux } \\
\text { cluster }\end{array}$ & alr7634-alr7636 & Putative copper efflux & & 5.1 & 0.002 \\
\hline
\end{tabular}

${ }^{1}$ Fold changes of genes upregulated or downregulated in low $\mathrm{CO}_{2}$, compared to high $\mathrm{CO}_{2}$, are coloured orange or green, respectively. In cases of multiple genes, average fold changes are shown; ${ }^{2} p$-values determined by moderated $t$-test. In cases of multiple genes, largest $p$-value is shown. 


\section{Discussion}

\subsection{Transcriptional Regulation in Response to $\mathrm{CO}_{2}$ Stepdown is Triggered by Metabolites}

Induction of the most strongly upregulated genes, the $\mathrm{HCO}_{3}{ }^{-}$transporters (Table 1), after $\mathrm{CO}_{2}$ stepdown, suggests a rapid transcriptional response that is highly sensitive to cellular $C_{i}$ levels. In some unicellular cyanobacteria, repression of the CCM genes by NdhR (also called CcmR) can be modulated by both 2OG and 2PG [12,15,65,82]. Increased cellular 2PG concentration caused by increased photorespiration in low $\mathrm{CO}_{2}$ leads to increased abundance of the NdhR-2PG complex that is unable to bind DNA to repress expression [4]. Additionally, declining 2OG levels due to lower $\mathrm{CO}_{2}$ fixation and potentially lower TCA cycle activity decrease the abundance of the NdhR-2OG repressor complex, although it is unclear whether 2OG levels would actually decrease after only $1 \mathrm{~h}$ in low $\mathrm{CO}_{2}$ due to the mobilisation of stored glycogen into the TCA cycle $[2,15,82,83]$. NADP ${ }^{+}$, another co-repressor of $\mathrm{NdhR}$ [82], is also theoretically far less abundant after $\mathrm{CO}_{2}$ stepdown, due to decreased $\mathrm{CO}_{2}$ fixation and lower NADPH consumption despite constant light conditions. Although a putative NdhR in Nostoc sp. PCC 7120 has not been studied, it appears that the LTTR encoded by all4986 represents such an orthologue, and that the strong downregulation of all4986 after $\mathrm{CO}_{2}$ stepdown led to de-repression of the NdhR regulon, which includes the $n d h R$ gene itself [84]. Previous transcriptomics studies have shown $n d h R$ expression to be upregulated in Synechocystis sp. PCC 6803 after $>3 \mathrm{~h}$ in low $\mathrm{C}_{\mathrm{i}}$ conditions [12,13], which is in contrast to the strong downregulation of all4986 seen here after $1 \mathrm{~h}$ (Table 3). This suggests that NdhR de-repression in response to $\mathrm{CO}_{2}$ stepdown may be transient, and/or that expression of the NdhR regulon is also controlled by other transcription factors [18]. In the current study, de-repression by the putative $\mathrm{NdhR}$ is proposed to have caused a rapid and strong increase in $\mathrm{HCO}_{3}{ }^{-}$and $\mathrm{CO}_{2}$ uptake under $\mathrm{C}$ limitation, with the upregulated cmp operon (Table 1) inducing further increase in $\mathrm{HCO}_{3}{ }^{-}$uptake. The $c m p$ inducer $\mathrm{CmpR}$ is activated by 2PG or RuBP [82,85], both of which are in higher concentrations after $\mathrm{CO}_{2}$ stepdown due to decreased $\mathrm{CO}_{2}$ fixation. Furthermore, cmpR expression is also auto-upregulated (Table 3) [57]. In Synechococcus sp. PCC 7942 CmpR additionally upregulates the expression of PSII core subunits [86,87], found upregulated also in the current study alongside factors for PSII photoprotection and turnover, and downregulation of most PSI genes (Table 2). The overlap between cellular responses to either low $\mathrm{CO}_{2}$ or high light stress is well documented $[12,20,86,88]$, highlighting insufficient electron sinks similarly created by both high light and low $\mathrm{CO}_{2}$, and resulting in the over-reduction of photosynthetic electron carriers [2]. Notably, several PSII photoprotection factors encoded by genes that were DE in the current study, including $p s b A I I I$, flv 4 and $\operatorname{sodB}$, were shown to be regulated together with Rubisco and other CCM genes by another LTTR in Nostoc sp. PCC 7120 called PacR [18], suggesting the likely involvement of PacR in the transcriptional reprogramming seen here.

In addition to the LTTR transcription factors, the transcriptional response to low $\mathrm{CO}_{2}$ is also regulated by LexA and the cyAbrB paralogues [89-92]. The vast change in expression of the hox operon after $\mathrm{CO}_{2}$ stepdown (Table 2) may be related to the activity of LexA [93] and/or cyAbrB [90,94-96]. In Synechocystis sp. PCC 6803, cyAbrB2 controls the expression of many CCM components that were likewise found to be upregulated in this study (Table 1) [90], while the cyAbrB2 orthologue in Nostoc sp. PCC 7120 regulates the expression of FeSOD [96], also upregulated here. Nostoc sp. PCC 7120 cyAbrB1 has been recently implicated in transcriptional regulation of heterocyst differentiation [97], demonstrating a role close to the interface of $C_{i}$ and $N$ availability that suggests cyAbrB1/2 were likely active in the transcription regulation observed in the current study.

Given the transcriptional activation of NtcA, the master regulator of $\mathrm{N}$ metabolism, by high levels of $2 \mathrm{OG}$ upon a shift to low $\mathrm{N}$ (high $\mathrm{C} / \mathrm{N}$ ratio) $[7,98,99]$, it is widely assumed that a decrease in $\mathrm{CO}_{2}$ leads to a decline in NtcA activity by decreasing the abundance of the 2OG-NtcA-PipX activator complex [100]. In the current study, lower NtcA activity was indeed evident in the downregulation of nir genes encoding $\mathrm{NO}_{3}{ }^{-}$uptake and metabolism (Table 1), as well as downregulation of the nir co-activator $n t c B$ (Table 3; reviewed in [101]). This transcriptional regulation would effectively bring $\mathrm{N}$ 
metabolism into alignment with decreased $\mathrm{C}$ metabolism after $\mathrm{CO}_{2}$ stepdown, despite the presence of $\mathrm{N}$ sources in the BG11 media. Overall, nearly $50 \%$ of genes downregulated in the current study have NtcA-binding promoters [71], although many NtcA-regulated genes, such as those involved in the uptake of $\mathrm{NH}_{3}$ and urea, regulation of GS-GOGAT enzymes, as well as NtcA itself [71,102-104], were not DE after $1 \mathrm{~h}$ in low $\mathrm{CO}_{2}$. The current work may therefore include only the early NtcA regulon. The NtcA-activated differentiation of vegetative cells to heterocysts occurs over approximately $24 \mathrm{~h}$, via a cascade of transcriptional regulation that includes early upregulation of the co-activator nrrA [33]. The rapid downregulation in the current work of some heterocyst regulators, including $n r r A$, may block the commencement of heterocyst differentiation in response to relative $\mathrm{N}$ excess over $\mathrm{C}$ after $\mathrm{CO}_{2}$ stepdown, and may signal an eventual decrease in the small number of heterocysts that are known to occur under high $\mathrm{C} / \mathrm{N}$ [105]. Downregulation of NtcA activity in the current study appears to indicate a decline in 2OG levels after only $1 \mathrm{~h}$ in low $\mathrm{CO}_{2}$, although an increased concentration of $\mathrm{NH}_{3}$ derived from 2PG metabolism can also explain suppression the NtcA regulon under low $\mathrm{CO}_{2}$ (low $\mathrm{C} / \mathrm{N}$ ratio) [83]. $\mathrm{N}$ excess under low $\mathrm{CO}_{2}$ is also evident in the $-2.2 \mathrm{FC}$ downregulated expression of cyanophycinase chb2 (all0571; not shown), which is regulated by NrrA, suggesting a decrease in the mobilisation of stored $\mathrm{N}$ under low $\mathrm{CO}_{2}$ (reviewed in [106]). It can also be argued that an increase in the ADP/ATP ratio under $\mathrm{CO}_{2}$ stepdown, caused by decreased photosynthetic electron transport and rapid changes in metabolism, increases the abundance of both the ADP-PII-PipX complex and the inactive form of NtcA [6].

The strong downregulation of operons involved in ferrous Fe import and Fe-S cluster assembly in the current work (Table 4) suggests a connection between cellular Fe homeostasis and C/N balance in Nostoc sp. PCC 7120, which has been explored [107]. The current results indicate a $\mathrm{CO}_{2}$ stepdown-induced cellular excess of $\mathrm{Fe}$ and other transition metals, which may be due to downregulation of Fe-rich PSI complexes (Table 2) [108] and/or an excess of reductant caused by insufficient electron sinks. Both conditions pose the danger of ROS formation, evidenced by upregulated expression of SOD, peroxiredoxin and protein chaperones.

\subsection{Altered C/N Balance Modulates the Energetic Strategy of Nostoc sp. PCC 7120}

The current study shows that a stepdown from $3 \% \mathrm{CO}_{2}$ in enriched air to $0.04 \% \mathrm{CO}_{2}$ (atmospheric) for just $1 \mathrm{~h}$ led to substantial reprogramming of global gene expression in Nostoc sp. PCC 7120 cultures. As discussed above, most of the transcriptional changes observed here can be directly attributed to metabolite signalling instigated by the alteration of the cellular $\mathrm{C} / \mathrm{N}$ balance (Figure 1 ), initiated by the decrease in $\mathrm{CO}_{2}$ concentration. Furthermore, these results highlight rapid transcriptional reprogramming of photosynthesis and energy metabolism in Nostoc sp. PCC 7120 in response to $\mathrm{CO}_{2}$ levels (Figure 2). High $\mathrm{CO}_{2}$ in light promotes a high rate of photosynthesis and the storage of photosynthate in the form of glycogen [13,109-111]. Strong expression of PEP synthase and PFOR under these conditions indicate glycolysis/gluconeogenesis through the metabolism of pyruvate, which is consumed in the TCA cycle to facilitate respiratory electron transport and to provide $2 \mathrm{OG}$ for amino acid synthesis (reviewed in $[112,113]$ ). Therefore, growth under $3 \% \mathrm{CO}_{2}$ somewhat resembles photomixotrophy, with photosynthetic and glycolytic metabolisms occurring concomitantly, even though glucose was not externally provided to cultures. Under these conditions, the cells experience a high $\mathrm{C} / \mathrm{N}$, which is evident in the relatively high expression of $\mathrm{N}$ metabolic genes, reflecting a cellular excess of $2 \mathrm{OG}[7,98,99]$. In high $\mathrm{CO}_{2}$, strong expression of Hox, which is important under mixotrophy and $\mathrm{N}$ deprivation [55], and PTOX, may provide a system to maintain redox poise [45], and in the case of Hox, also store surplus energy as $\mathrm{H}_{2}$ [53]. The transfer of Synechocystis sp. PCC 6803 and Synechococcus elongatus PCC 7942 cultures from high to low $\mathrm{CO}_{2}$ showed that the toxic effects of 2PG transiently block Calvin-Benson-Bassham (CBB) activity $[15,20,83]$ and this is also evident here in the upregulated expression of PSII repair, photoprotection and ROS scavenging enzymes in Nostoc sp. PCC 7120, which indicate over-reduction of the photosynthetic electron transport chain. Interestingly, detoxification of 2PG appeared to be downregulated through repression of alr1004 
during $\mathrm{CO}_{2}$ stepdown (Table 2), perhaps highlighting the importance of the metabolite for signalling during the early stages of $C_{i}$ deprivation. We also observed downregulation of the terminal proteins in the phycobilisomes, suggesting modified harvesting of light energy to alleviate excitation pressure on the photosynthetic system. Under these conditions, inhibition of photoassimilation is compensated by glycolysis of stored glucose and CBB intermediates, providing an important supply of substrates for anaplerosis of the CBB and TCA cycles during acclimation to the transition $[83,114,115]$. In the current work, enhanced glycolytic activity is indicated by the upregulation of NDH-1, suggesting an increased reliance on respiratory electron transport for ATP generation, while strong downregulation of PEP synthase and PFOR after $\mathrm{CO}_{2}$ stepdown may prevent diversion of pyruvate away from the TCA cycle. Notably, PEP abundance increased substantially in Synechocystis sp. PCC 6803 and Synechococcus elongatus PCC 7942 after a shift from high to low $\mathrm{CO}_{2}[20,83]$, while genes encoding both pyruvate kinase and PFOR were highly expressed in Synechococcus elongatus PCC 7942 after long-term acclimation to low $\mathrm{CO}_{2}$, but not directly after the transition [20]. These findings support the results of this study and suggest that the metabolism of PEP and pyruvate are tightly regulated after the transition to low $\mathrm{CO}_{2}$. This may be linked to the role of PEP and pyruvate as substrates to anaplerotic carbon fixation to produce TCA cycle intermediates oxaloacetate and malate (reviewed in [116]). During the adjustment to a low C/N ratio, TCA cycle activity generates $2 \mathrm{OG}$ for amino acid synthesis, utilising excess $\mathrm{NH}_{4}^{+}$generated through 2PG detoxification [11,83].

This work has revealed rapid transcriptional reprogramming in Nostoc sp. PCC 7120 in response to a decrease in $\mathrm{C}_{\mathrm{i}}$ availability, namely strong upregulation of CCM components and photoprotection, and downregulation of $\mathrm{N}$ uptake and early stages of heterocyst differentiation. Despite the vast increase in $\mathrm{HCO}_{3}{ }^{-}$uptake, glycolysis of stored $\mathrm{C}$ apparently plays an important role in energy metabolism at low $\mathrm{CO}_{2}$, likely due to 2PG-induced inhibition of the $\mathrm{CBB}$ cycle. A majority of the transcriptional effects induced by low $\mathrm{CO}_{2}$ in Nostoc sp. PCC 7120 can be attributed to 2PG modulation of CmpR and a putative NdhR homologue; however, the effects of changing abundance of $2 \mathrm{OG}$ and NtcA activity after $1 \mathrm{~h}$ in $0.04 \% \mathrm{CO}_{2}$, as well as the roles of other transcriptional regulators cannot be discounted. Finally, this work highlights the sensitivity of Nostoc sp. PCC 7120 to factors that influence the cellular $\mathrm{C} / \mathrm{N}$ balance and demonstrates the speed at which genetic and metabolic reprogramming can take place, allowing rapid acclimation for surviving and thriving in the fluctuating environment.

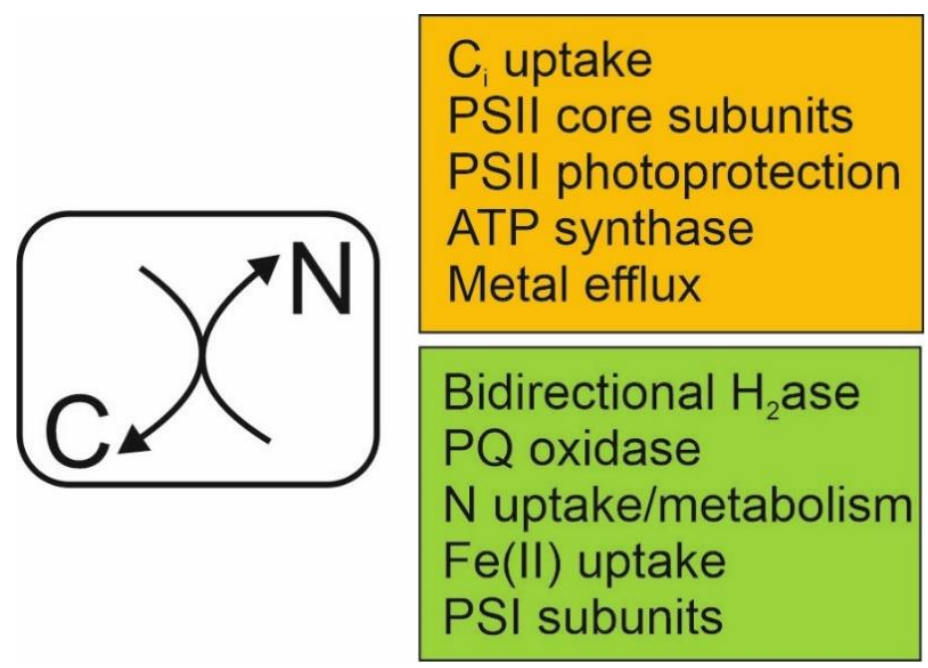

Figure 1. The transcriptional response of Nostoc sp. PCC 7120 cells to a change in the cellular concentrations of carbon and nitrogen $\left(\mathrm{C} / \mathrm{N}\right.$ balance). Decrease in the external $\mathrm{CO}_{2}$ concentration of cultures causes a decline in the cellular $\mathrm{C} / \mathrm{N}$ balance signalled by an increased production of $2 \mathrm{PG}$ and decreased 2OG levels relative to $\mathrm{N}$. This metabolic change leads to upregulation of genes encoding processes depicted in orange, and downregulation of genes encoding processes depicted in green. 
A. $\mathrm{High} \mathrm{CO}_{2}$
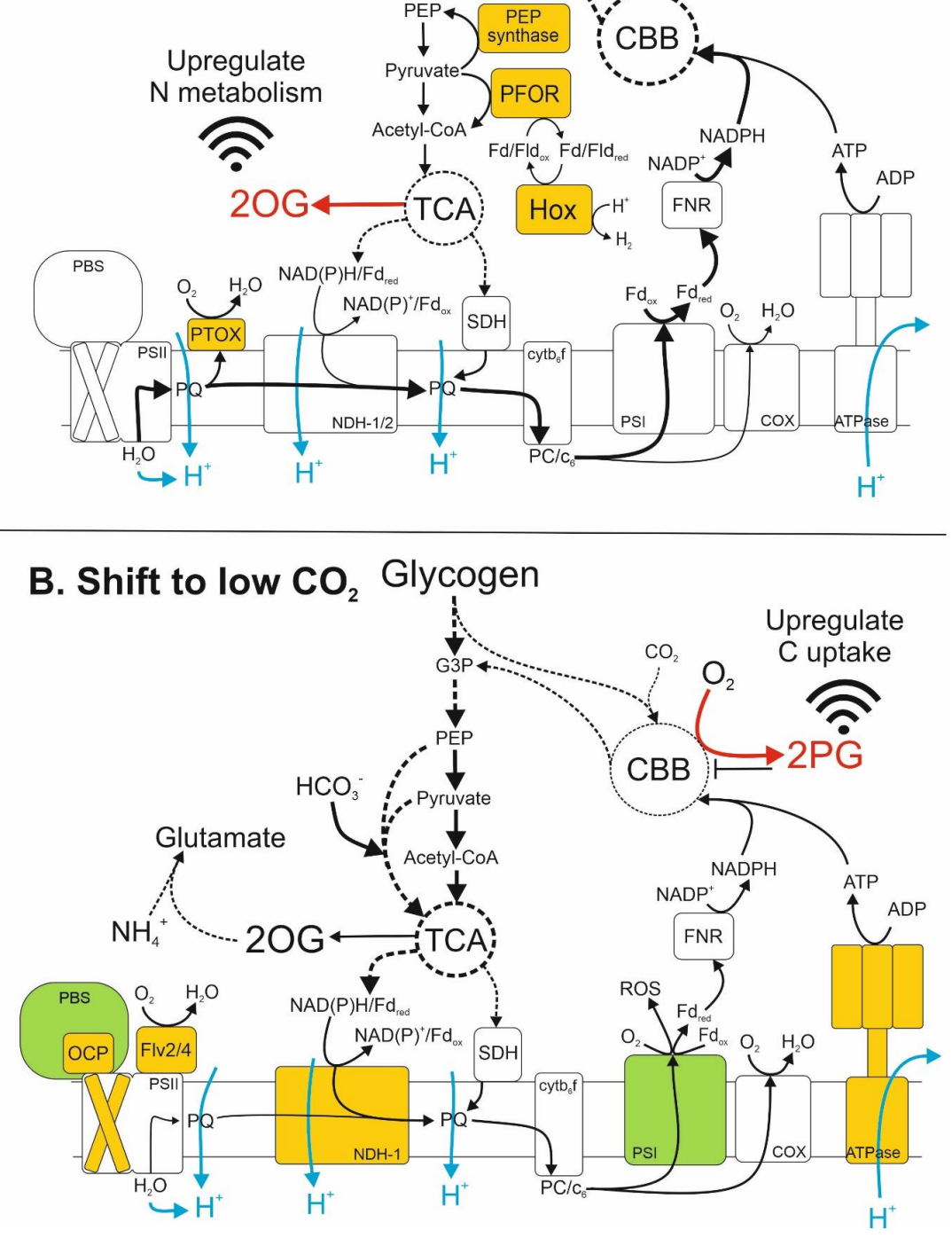

Figure 2. Schematic representation of the interactions between photosynthetic/respiratory electron transport and accumulation of 2OG and 2PG for signalling the C/N balance in Nostoc sp. PCC 7120 cells. Scheme is based on global transcriptomic profiling of Nostoc sp. PCC 7120 cultures under high $\mathrm{CO}_{2}$ conditions and after $\mathrm{CO}_{2}$ stepdown. (A) Under $3 \% \mathrm{CO}_{2}$, efficient photosynthetic electron transport and Calvin-Benson-Bassham (CBB) cycle activity enables gluconeogenesis of glyceraldehyde-3-phosphate (G3P), leading to accumulation of carbohydrate storage in the form of glycogen. Glycolysis of glycogen stores and/or photosynthate supplies pyruvate to the incomplete tricarboxylic acid (TCA) cycle, which produces reductant, ATP and succinate to drive respiratory electron transport through $\mathrm{NAD}(\mathrm{P}) \mathrm{H}$-dehydrogenase $(\mathrm{NDH})$ and succinate dehydrogenase $(\mathrm{SDH})$, as well as other cellular processes. The TCA cycle also generates 2-oxoglutarate (2OG), which accumulates under high $\mathrm{CO}_{2}$ due to a relative shortage of $\mathrm{NH}_{4}{ }^{+}$and glutamine. 2OG operates as a signal for upregulating genes involved in $\mathrm{N}$ uptake and metabolism. Strong expression of phosphoenolpyruvate (PEP) synthase converts pyruvate to PEP. Pyruvate:ferredoxin/flavodoxin oxidoreductase (PFOR) converts pyruvate to acetyl-CoA, reducing oxidised ferredoxin/flavodoxin $\left(\mathrm{Fd} / \mathrm{Flv}_{\mathrm{ox}}\right)$ that is consumed by bidirectional hydrogenase (Hox) for storage of excess energy as $\mathrm{H}_{2}$. Strong expression of plastoquinone terminal oxidase (PTOX) maintains redox homeostasis of the plastoquinone (PQ) pool during high photosynthetic electron transport, while cytochrome 6 oxidase (COX) maintains the redox poise of lumenal electron 
carriers cytochrome $\mathrm{c}_{6}\left(\mathrm{c}_{6}\right)$ and plastocyanin $(\mathrm{PC})$. Genes encoding factors coloured orange are highly expressed under $3 \% \mathrm{CO}_{2}$ and strongly downregulated by the shift to $0.04 \% \mathrm{CO}_{2}$. (B) After $1 \mathrm{~h}$ in $0.04 \%$ $\mathrm{CO}_{2}$, a deficiency of $\mathrm{CO}_{2}$ electron acceptors leads to oxygenation of Rubisco, causing photorespiration that produces 2-phosphoglycolate (2PG). The CBB cycle and other metabolic pathways are inhibited by $2 \mathrm{PG}$, which also signals upregulation of the transcriptomic response to low $\mathrm{CO}_{2}$. Low CBB activity causes over-reduction of the photosynthetic electron transport chain, leading to the production of reactive oxygen species (ROS) at photosystem I (PSI) and downregulation of PSI subunits. Increased reducing pressure on photosystem II (PSII) also causes upregulation of the PSII repair cycle and upregulation of PSII photoprotection by flavoproteins (Flv2/4) and orange carotenoid proteins (OCPs), as well as downregulation of phycoerythrocyanin in the phycobilisome (PBS). Glycolysis triggered by decreased $\mathrm{CO}_{2}$ assimilation provides substrates for anaplerotic supplementation of the CBB and TCA cycles, including the production of oxaloacetate from PEP and bicarbonate $\left(\mathrm{HCO}_{3}{ }^{-}\right)$. TCA cycle activity also produces 2OG for glutamate production from excess ammonium $\left(\mathrm{NH}_{4}{ }^{+}\right)$resulting from the shift from $3 \%$ to $0.04 \% \mathrm{CO}_{2}$. Genes encoding factors coloured orange or green are upregulated or downregulated, respectively, $1 \mathrm{~h}$ after the shift from $3 \%$ to $0.04 \% \mathrm{CO}_{2}$. Black arrows indicate the movement of electrons or ATP, dashed arrows summarise multiple enzymatic reactions in carbohydrate metabolism, blue arrows indicate the movement of protons. The red arrow in (A) shows the production of 2OG by TCA cycle activity, the red arrow in (B) shows the production of 2PG by Rubisco oxygenation in the CBB cycle and the black bar in (B) indicates CBB inhibition by 2PG.

Author Contributions: Conceptualization, P.J.G., E.-M.A.; investigation and analysis, P.J.G.; original draft preparation, P.J.G.; writing—review and editing, P.J.G., D.M.-P., E.-M.A.; funding acquisition, P.J.G., E.-M.A. All authors have read and agreed to the published version of the manuscript.

Funding: This research was funded by Academy of Finland, projects 26080341 (P.J.G.) and 307335 (E.-M.A.), and the Jane and Aatos Erkko Foundation (E.-M.A.).

Acknowledgments: The authors acknowledge Julia Walter for the growth of cultures and the isolation of RNA used in this study.

Conflicts of Interest: The authors declare no conflict of interest. The funders had no role in the design of the study; in the collection, analyses, or interpretation of data; in the writing of the manuscript, or in the decision to publish the results.

\section{References}

1. Herrero, A.; Flores, E. Genetic responses to carbon and nitrogen availability in Anabaena. Environ. Microbiol. 2019, 21, 1-17. [CrossRef] [PubMed]

2. Burnap, R.L.; Hagemann, M.; Kaplan, A. Regulation of $\mathrm{CO}_{2}$ Concentrating Mechanism in Cyanobacteria. Life 2015, 5, 348-371. [CrossRef] [PubMed]

3. Huergo, L.F.; Dixon, R. The Emergence of 2-Oxoglutarate as a Master Regulator Metabolite. Microbiol. Mol. Biol. Rev. 2015, 79, 419-435. [CrossRef]

4. Zhang, C.-C.; Zhou, C.-Z.; Burnap, R.L.; Peng, L. Carbon/Nitrogen Metabolic Balance: Lessons from Cyanobacteria. Trends Plant Sci. 2018, 23, 1116-1130. [CrossRef]

5. Flores, E.; Frías, J.E.; Rubio, L.M.; Herrero, A. Photosynthetic nitrate assimilation in cyanobacteria. Photosynth. Res. 2005, 83, 117-133. [CrossRef]

6. Forchhammer, K.; Selim, K.A. Carbon/nitrogen homeostasis control in cyanobacteria. FEMS Microbiol. Rev. 2019, 44, 33-53. [CrossRef]

7. Muro-Pastor, M.I.; Reyes, J.C.; Florencio, F.J. Cyanobacteria perceive nitrogen status by sensing intracellular 2-oxoglutarate levels. J. Biol. Chem. 2001, 276, 38320-38328. [PubMed]

8. Vázquez-Bermúdez, M.F.; Herrero, A.; Flores, E. 2-Oxoglutarate increases the binding affinity of the NtcA (nitrogen control) transcription factor for the Synechococcus glnA promoter. FEBS Lett. 2002, 512, 71-74. [CrossRef]

9. Li, J.-H.; Laurent, S.; Konde, V.; Bédu, S.; Zhang, C.-C. An increase in the level of 2-oxoglutarate promotes heterocyst development in the cyanobacterium Anabaena sp. strain PCC 7120. Microbiology 2003, 149, 3257-3263. [CrossRef] 
10. Haimovich-Dayan, M.; Lieman-Hurwitz, J.; Orf, I.; Hagemann, M.; Kaplan, A. Does 2-phosphoglycolate serve as an internal signal molecule of inorganic carbon deprivation in the cyanobacterium Synechocystis sp. PCC 6803? Environ. Microbiol. 2015, 17, 1794-1804. [CrossRef]

11. Hagemann, M.; Bauwe, H. Photorespiration and the potential to improve photosynthesis. Curr. Opin. Chem. Biol. 2016, 35, 109-116. [CrossRef] [PubMed]

12. Wang, H.-L.; Postier, B.L.; Burnap, R.L. Alterations in Global Patterns of Gene Expression in Synechocystis sp. PCC 6803 in Response to Inorganic Carbon Limitation and the Inactivation of ndhR, a LysR Family Regulator. J. Biol. Chem. 2004, 279, 5739-5751. [CrossRef] [PubMed]

13. Eisenhut, M.; Von Wobeser, E.A.; Jonas, L.; Schubert, H.; Ibelings, B.W.; Bauwe, H.; Matthijs, H.C.; Hagemann, M. Long-Term Response toward Inorganic Carbon Limitation in Wild Type and Glycolate Turnover Mutants of the Cyanobacterium Synechocystis sp. Strain PCC 6803. Plant Physiol. 2007, 144, 1946-1959. [CrossRef] [PubMed]

14. Kaplan, A.; Hagemann, M.; Bauwe, H.; Kahlon, S.; Ogawa, T. Carbon acquisition by cyanobacteria: Mechanisms, comparative genomics and evolution. In The Cyanobacteria: Molecular Biology, Genomics and Evolution; Herrero, A., Flores, E., Eds.; Caister Academic Press: Norwich, UK, 2008; pp. 305-323.

15. Klähn, S.; Orf, I.; Schwarz, D.; Matthiessen, J.K.; Kopka, J.; Hess, W.R.; Hagemann, M. Integrated Transcriptomic and Metabolomic Characterization of the Low-Carbon Response Using an ndhR Mutant of Synechocystis sp. PCC 68031. Plant Physiol. 2015, 169, 1540-1556. [CrossRef]

16. Wolk, C.P.; Ernst, A.; Elhai, J. Heterocyst Metabolism and Development. In The Molecular Biology of Cyanobacteri; Springer: Dordrecht, The Netherlands, 1994; pp. 769-823. [CrossRef]

17. Herrero, A.; Muro-Pastor, A.M.; Valladares, A.; Flores, E. Cellular differentiation and the NtcA transcription factor in filamentous cyanobacteria. FEMS Microbiol. Rev. 2004, 28, 469-487. [CrossRef]

18. Picossi, S.; Flores, E.; Herrero, A. The LysR-type transcription factor PacR is a global regulator of photosynthetic carbon assimilation inAnabaena. Environ. Microbiol. 2015, 17, 3341-3351. [CrossRef]

19. Allahverdiyeva, Y.; Vainonen, J.P.; Vorontsova, N.; Keränen, M.; Carmel, D.; Aro, E.-M. Dynamic Changes in the Proteome of Synechocystis 6803 in Response to $\mathrm{CO}_{2}$ Limitation Revealed by Quantitative Proteomics. J. Proteome Res. 2010, 9, 5896-5912. [CrossRef]

20. Schwarz, D.; Nodop, A.; Hüge, J.; Purfürst, S.; Forchhammer, K.; Michel, K.-P.; Bauwe, H.; Kopka, J.; Hagemann, M. Metabolic and Transcriptomic Phenotyping of Inorganic Carbon Acclimation in the Cyanobacterium Synechococcus elongatus PCC 7942. Plant Physiol. 2011, 155, 1640-1655. [CrossRef]

21. Price, G.D.; Woodger, F.J.; Badger, M.R.; Howitt, S.M.; Tucker, L. Identification of a SulP-type bicarbonate transporter in marine cyanobacteria. Proc. Natl. Acad. Sci. USA 2004, 101, 18228-18233. [CrossRef]

22. McGinn, P.J.; Price, G.D.; Maleszka, R.; Badger, M.R. Inorganic Carbon Limitation and Light Control the Expression of Transcripts Related to the $\mathrm{CO}_{2}$-Concentrating Mechanism in the Cyanobacterium Synechocystis sp. Strain PCC6803. Plant Physiol. 2003, 132, 218-229. [CrossRef]

23. Rippka, R.; Stanier, R.Y.; Deruelles, J.; Herdman, M.; Waterbury, J.B. Generic Assignments, Strain Histories and Properties of Pure Cultures of Cyanobacteria. Microbiology 1979, 111, 1-61. [CrossRef]

24. Walter, J.; Lynch, F.; Battchikova, N.; Aro, E.-M.; Gollan, P.J. Calcium impacts carbon and nitrogen balance in the filamentous cyanobacterium Anabaena sp. PCC 7120. J. Exp. Bot. 2016, 67, 3997-4008. [CrossRef] [PubMed]

25. Omata, T.; Price, G.D.; Badger, M.R.; Okamura, M.; Gohta, S.; Ogawa, T. Identification of an ATP-binding cassette transporter involved in bicarbonate uptake in the cyanobacterium Synechococcus sp. strain PCC 7942. Proc. Natl. Acad. Sci. USA 1999, 96, 13571-13576. [CrossRef] [PubMed]

26. Shibata, M.; Katoh, H.; Sonoda, M.; Ohkawa, H.; Shimoyama, M.; Fukuzawa, H.; Kaplan, A.; Ogawa, T. Genes Essential to Sodium-dependent Bicarbonate Transport in Cyanobacteria: Function and phylogenetic analysis. J. Biol. Chem. 2002, 277, 18658-18664. [CrossRef] [PubMed]

27. Blanco-Rivero, A.; Leganés, F.; Fernández-Valiente, E.; Calle, P.; Fernández-Piñas, F. mrpA, a gene with roles in resistance to $\mathrm{Na}^{+}$and adaptation to alkaline $\mathrm{pH}$ in the cyanobacterium Anabaena sp. PCC7120. Microbiology 2005, 151, 1671-1682. [CrossRef] [PubMed]

28. Fukaya, F.; Promden, W.; Hibino, T.; Tanaka, Y.; Nakamura, T.; Takabe, T. An Mrp-like cluster in the halotolerant cyanobacterium Aphanothece halophytica functions as a $\mathrm{Na}^{+} / \mathrm{H}^{+}$antiporter. Appl. Environ. Microbiol. 2009, 75, 6626-6629. [CrossRef] 
29. Allahverdiyeva, Y.; Aro, E.-M.; Nixon, P.J. Structure and Physiological Function of NDH-1 Complexes in Cyanobacteria. In Bioenergetic Processes of Cyanobacteria; Springer: Dordrecht, The Netherlands, 2011; pp. 445-467. [CrossRef]

30. Kaneko, T.; Nakamura, Y.; Wolk, C.P.; Kuritz, T.; Sasamoto, S.; Watanabe, A.; Iriguchi, M.; Ishikawa, A.; Kawashima, K.; Kimura, T.; et al. Complete Genomic Sequence of the Filamentous Nitrogen-fixing Cyanobacterium Anabaena sp. Strain PCC 7120. DNA Res. 2001, 8, 205-213. [CrossRef]

31. Frías, J.E.; Flores, E.; Herrero, A. Nitrate assimilation gene cluster from the heterocyst-forming cyanobacterium Anabaena sp. strain PCC 7120. J. Bacteriol. 1997, 179, 477-486. [CrossRef]

32. Frías, J.E.; Flores, E. Negative Regulation of Expression of the Nitrate Assimilation nirA Operon in the Heterocyst-Forming Cyanobacterium Anabaena sp. Strain PCC 7120. J. Bacteriol. 2010, 192, 2769-2778. [CrossRef]

33. Flores, E.; Picossi, S.; Valladares, A.; Herrero, A. Transcriptional regulation of development in heterocyst-forming cyanobacteria. Biochim. Biophys. Acta Bioenergy 2019, 1862, 673-684. [CrossRef]

34. Kumar, K.; Mella-Herrera, R.A.; Golden, J.W. Cyanobacterial Heterocysts. Cold Spring Harb. Perspect. Biol. 2010, 2, a000315. [CrossRef] [PubMed]

35. Maldener, I.; Muro-Pastor, A.M. Cyanobacterial Heterocysts. In Encyclopedia of Life Sciences; John Wiley \& Sons, Ltd.: Chichester, UK, 2010. [CrossRef]

36. Aro, E.-M.; Virgin, I.; Andersson, B. Photoinhibition of Photosystem II. Inactivation, protein damage and turnover. Biochim. Biophys. Acta Bioenergy 1993, 1143, 113-134. [CrossRef]

37. Komenda, J.; Hassan, H.A.; Diner, B.A.; Debus, R.J.; Barber, J.; Nixon, P.J. Degradation of the Photosystem II $\mathrm{D}_{1}$ and $\mathrm{D}_{2}$ proteins in different strains of the cyanobacterium Synechocystis PCC 6803 varying with respect to the type and level of psbA transcript. Plant Mol. Biol. 2000, 42, 635-645. [CrossRef]

38. Silva, P.; Thompson, E.P.; Bailey, S.; Kruse, O.; Mullineaux, C.W.; Robinson, C.; Mann, N.H.; Nixon, P.J. FtsH Is Involved in the Early Stages of Repair of Photosystem II in Synechocystis sp PCC 6803. Plant Cell 2003, 15, 2152-2164. [CrossRef] [PubMed]

39. Komenda, J.; Barker, M.; Kuviková, S.; De Vries, R.; Mullineaux, C.W.; Tichý, M.; Nixon, P.J. The FtsH Protease slr0228 Is Important for Quality Control of Photosystem II in the Thylakoid Membrane of Synechocystis sp. PCC 6803. J. Biol. Chem. 2006, 281, 1145-1151. [CrossRef] [PubMed]

40. Eisenhut, M.; Georg, J.; Klähn, S.; Sakurai, I.; Mustila, H.; Zhang, P.; Hess, W.R.; Aro, E.-M. The Antisense RNA As1_flv4 in the Cyanobacterium Synechocystis sp. PCC 6803 Prevents Premature Expression of the flv4-2 Operon upon Shift in Inorganic Carbon Supply. J. Biol. Chem. 2012, 287, 33153-33162. [CrossRef]

41. Bersanini, L.; Battchikova, N.; Jokel, M.; Rehman, A.; Vass, I.; Allahverdiyeva, Y.; Aro, E.M. Flavodiiron protein Flv2/Flv4-related photoprotective mechanism dissipates excitation pressure of PSII in cooperation with phycobilisomes in cyanobacteria. Plant Physiol. 2014, 164, 805-818. [CrossRef]

42. Gwizdala, M.; Wilson, A.; Kirilovsky, D. In Vitro Reconstitution of the Cyanobacterial Photoprotective Mechanism Mediated by the Orange Carotenoid Protein in Synechocystis PCC 6803. Plant Cell 2011, 23, 2631-2643. [CrossRef]

43. López-Igual, R.; Wilson, A.; Leverenz, R.L.; Melnicki, M.R.; De Carbon, C.B.; Sutter, M.; Turmo, A.; Perreau, F.; Kerfeld, C.A.; Kirilovsky, D. Different Functions of the Paralogs to the N-Terminal Domain of the Orange Carotenoid Protein in the Cyanobacterium Anabaena sp. PCC 7120. Plant Physiol. 2016, 171, 1852-1866. [CrossRef]

44. Kufryk, G.; Hernandez-Prieto, M.A.; Kieselbach, T.; Miranda, H.; Vermaas, W.; Funk, C. Association of small CAB-like proteins (SCPs) of Synechocystis sp. PCC 6803 with Photosystem II. Photosynth. Res. 2008, 95, 135-145. [CrossRef]

45. Lea-smith, D.J.; Bombelli, P.; Vasudevan, R.; Howe, C.J. Photosynthetic, Respiratory and extracellular electron transport pathways in cyanobacteria. Biochim. Biophys. Acta Bioenergy 2016, 1857, $247-255$. [CrossRef] [PubMed]

46. González, A.; Fillat, M.F. Overexpression, immunodetection, and site-directed mutagenesis of Anabaena sp. PCC 7120 flavodoxin: A comprehensive laboratory practice on molecular biology. Biochem. Mol. Biol. Educ. 2018, 46, 493-501. [CrossRef]

47. Laudenbach, D.E.; Straus, N.A. Characterization of a cyanobacterial iron stress-induced gene similar to psbC. J. Bacteriol. 1988, 170, 5018-5026. [CrossRef] [PubMed] 
48. Torrado, A.; Ramírez-Moncayo, C.; Navarro, J.A.; Mariscal, V.; Molina-Heredia, F.P. Cytochrome c6 is the main respiratory and photosynthetic soluble electron donor in heterocysts of the cyanobacterium Anabaena sp. PCC 7120. Biochim. Biophys. Acta Bioenergy 2019, 1860, 60-68. [CrossRef] [PubMed]

49. Ermakova, M.; Allahverdiyeva, Y.; Allahverdiyeva, Y.; Aro, E.-M.; Allahverdiyeva, Y. Novel heterocyst-specific flavodiiron proteins in Anabaena sp. PCC 7120. FEBS Lett. 2013, 587, 82-87. [CrossRef]

50. Swanson, R.V.; De Lorimier, R.; Glazer, A.N. Genes encoding the phycobilisome rod substructure are clustered on the Anabaena chromosome: Characterization of the phycoerythrocyanin operon. J. Bacteriol. 1992, 174, 2640-2647. [CrossRef]

51. Ducret, A.; Sidler, W.; Wehrli, E.; Frank, G.; Zuber, H. Isolation, Characterization and Electron Microscopy Analysis of A Hemidiscoidal Phycobilisome Type from the Cyanobacterium Anabaena sp. PCC 7120. JBIC J. Biol. Inorg. Chem. 1996, 236, 1010-1024. [CrossRef]

52. Khanna, N.; Lindblad, P. Cyanobacterial Hydrogenases and Hydrogen Metabolism Revisited: Recent Progress and Future Prospects. Int. J. Mol. Sci. 2015, 16, 10537-10561. [CrossRef]

53. Appel, J.; Phunpruch, S.; Steinmüller, K.; Schulz, R. The bidirectional hydrogenase of Synechocystis sp. PCC 6803 works as an electron valve during photosynthesis. Arch. Microbiol. 2000, 173, 333-338. [CrossRef]

54. Carrieri, D.; Wawrousek, K.; Eckert, C.; Yu, J.; Maness, P. The role of the bidirectional hydrogenase in cyanobacteria. Bioresour. Technol. 2011, 102, 8368-8377. [CrossRef]

55. Gutekunst, K.; Chen, X.; Schreiber, K.; Kaspar, U.; Makam, S.; Appel, J. The Bidirectional NiFe-hydrogenase in Synechocystis sp. PCC 6803 Is Reduced by Flavodoxin and Ferredoxin and Is Essential under Mixotrophic, Nitrate-limiting Conditions. J. Biol. Chem. 2014, 289, 1930-1937. [CrossRef] [PubMed]

56. Omata, T.; Gohta, S.; Takahashi, Y.; Harano, Y.; Maeda, S.-I. Involvement of a CbbR Homolog in Low $\mathrm{CO}_{2}$-Induced Activation of the Bicarbonate Transporter Operon in Cyanobacteria. J. Bacteriol. 2001, 183, 1891-1898. [CrossRef] [PubMed]

57. López-Igual, R.; Picossi, S.; López-Garrido, J.; Flores, E.; Herrero, A. N and C control of ABC-type bicarbonate transporter $\mathrm{Cmp}$ and its LysR-type transcriptional regulator $\mathrm{CmpR}$ in a heterocyst-forming cyanobacterium, Anabaena sp. Environ. Microbiol. 2012, 14, 1035-1048. [CrossRef] [PubMed]

58. Brahamsha, B.; Haselkorn, R. Identification of multiple RNA polymerase sigma factor homologs in the cyanobacterium Anabaena sp. strain PCC 7120: Cloning, expression, and inactivation of the sigB and sigC genes. J. Bacteriol. 1992, 174, 7273-7282. [CrossRef]

59. Caslake, L.F.; Gruber, T.M.; Bryant, N.A. Expression of two alternative sigma factors of Synechococcus sp. strain PCC 7002 is modulated by carbon and nitrogen stress. Microbiology 1997, 143, 3807-3818. [CrossRef]

60. Muro-Pastor, A.M.; Herrero, A.; Flores, E. Nitrogen-Regulated Group 2 Sigma Factor from Synechocystis sp. Strain PCC 6803 Involved in Survival under Nitrogen Stress. J. Bacteriol. 2001, 183, 1090-1095. [CrossRef]

61. Tuominen, I.; Pollari, M.; Tyystjärvi, E.; Tyystjärvi, T. The SigB $\sigma$ factor mediates high-temperature responses in the cyanobacterium Synechocystis sp. PCC6803. FEBS Lett. 2006, 580, 319-323. [CrossRef]

62. Hakkila, K.; Antal, T.; Gunnelius, L.; Kurkela, J.; Matthijs, H.C.; Tyystjärvi, E.; Tyystjärvi, T. Group 2 Sigma Factor Mutant sigCDE of the Cyanobacterium Synechocystis sp. PCC 6803 Reveals Functionality of Both Carotenoids and Flavodiiron Proteins in Photoprotection of Photosystem II. Plant Cell Physiol. 2013, 54, 1780-1790. [CrossRef]

63. Summerfield, T.C.; Nagarajan, S.; Sherman, L.A. Gene expression under low-oxygen conditions in the cyanobacterium Synechocystis sp. PCC 6803 demonstrates Hik31-dependent and -independent responses. Microbiology 2011, 157, 301-312. [CrossRef]

64. Nagarajan, S.; Sherman, D.M.; Shaw, I.; Sherman, L.A. Functions of the Duplicated hik31 Operons in Central Metabolism and Responses to Light, Dark, and Carbon Sources in Synechocystis sp. Strain PCC 6803. J. Bacteriol. 2011, 194, 448-459. [CrossRef]

65. Jiang, Y.-L.; Wang, X.-P.; Sun, H.; Han, S.-J.; Li, W.-F.; Cui, N.; Lin, G.-M.; Zhang, J.-Y.; Cheng, W.; Cao, D.-D.; et al. Coordinating carbon and nitrogen metabolic signaling through the cyanobacterial global repressor NdhR. Proc. Natl. Acad. Sci. USA 2017, 115, 403-408. [CrossRef]

66. Frías, J.E.; Flores, E.; Herrero, A. Activation of the Anabaena nir operon promoter requires both NtcA (CAP family) and NtcB (LysR family) transcription factors. Mol. Microbiol. 2000, 38, 613-625. [CrossRef] [PubMed] 
67. Liang, J.; Scappino, L.; Haselkorn, R. The patB gene product, required for growth of the cyanobacterium Anabaena sp. strain PCC 7120 under nitrogen-limiting conditions, contains ferredoxin and helix-turn-helix domains. J. Bacteriol. 1993, 175, 1697-1704. [CrossRef] [PubMed]

68. Hebbar, P.B.; Curtis, S.E. Characterization of devH, a Gene Encoding a Putative DNA Binding Protein Required for Heterocyst Function in Anabaena sp. Strain PCC 7120. J. Bacteriol. 2000, 182, 3572-3581. [CrossRef] [PubMed]

69. Jones, K.M.; Buikema, W.J.; Haselkorn, R. Heterocyst-Specific Expression of patB, a Gene Required for Nitrogen Fixation in Anabaena sp. Strain PCC 7120. J. Bacteriol. 2003, 185, 2306-2314. [CrossRef]

70. Ehira, S.; Ohmori, M. NrrA, a nitrogen-responsive response regulator facilitates heterocyst development in the cyanobacterium Anabaena sp. strain PCC 7120. Mol. Microbiol. 2006, 59, 1692-1703. [CrossRef]

71. Picossi, S.; Flores, E.; Herrero, A. ChIP analysis unravels an exceptionally wide distribution of DNA binding sites for the NtcA transcription factor in a heterocyst-forming cyanobacterium. BMC Genom. 2014, 15, 22. [CrossRef]

72. Tsujimoto, R.; Kamiya, N.; Fujita, Y. Identification of a cis-acting element in nitrogen fixation genes recognized by $\mathrm{CnfR}$ in the nonheterocystous nitrogen-fixing cyanobacterium Leptolyngbya boryana. Mol. Microbiol. 2016, 101, 411-424. [CrossRef]

73. Ramírez, M.E.; Hebbar, P.B.; Zhou, R.; Wolk, C.P.; Curtis, S.E. Anabaena sp. Strain PCC 7120 Gene devH Is Required for Synthesis of the Heterocyst Glycolipid Layer. J. Bacteriol. 2005, 187, 2326-2331. [CrossRef]

74. Ehira, S.; Ohmori, M. NrrA directly regulates expression of the fraF gene and antisense RNAs for fraE in the heterocyst-forming cyanobacterium Anabaena sp. strain PCC 7120. Microbiology 2014, 160, 844-850. [CrossRef]

75. Katoh, H.; Hagino, N.; Grossman, A.R.; Ogawa, T. Genes Essential to Iron Transport in the Cyanobacterium Synechocystis sp. Strain PCC 6803. J. Bacteriol. 2001, 183, 2779-2784. [CrossRef] [PubMed]

76. Fresenborg, L.S.; Graf, J.; Schätzle, H.; Schleiff, E. Iron homeostasis of cyanobacteria: Advancements in siderophores and metal transporters. In Advances in Cyanobacterial Biology; Academic Press: Cambridge, MA, USA, 2020. [CrossRef]

77. Shen, G.; Balasubramanian, R.; Wang, T.; Wu, Y.; Hoffart, L.M.; Krebs, C.; Bryant, N.A.; Golbeck, J.H. SufR Coordinates Two $[4 \mathrm{Fe}-4 \mathrm{~S}]^{2+}, 1+$ Clusters and Functions as a Transcriptional Repressor of the sufBCDS Operon and an Autoregulator of sufR in Cyanobacteria. J. Biol. Chem. 2007, 282, 31909-31919. [CrossRef] [PubMed]

78. Shcolnick, S.; Summerfield, T.C.; Reytman, L.; Sherman, L.A.; Keren, N. The Mechanism of Iron Homeostasis in the Unicellular Cyanobacterium Synechocystis sp. PCC 6803 and Its Relationship to Oxidative Stress. Plant Physiol. 2009, 150, 2045-2056. [CrossRef]

79. Vuorijoki, L.; Tiwari, A.; Kallio, P.T.; Aro, E.-M. Inactivation of iron-sulfur cluster biogenesis regulator SufR in Synechocystis sp. PCC 6803 induces unique iron-dependent protein-level responses. Biochim. Biophys. Acta Gen. Subj. 2017, 1861, 1085-1098. [CrossRef]

80. Garcia-Dominguez, M.; López-Maury, L.; Florencio, F.J.; Reyes, J.C.; Braunstein, M.; Brown, A.M.; Kurtz, S.; Jacobs, W.R. A Gene Cluster Involved in Metal Homeostasis in the Cyanobacterium Synechocystis sp. Strain PCC 6803. J. Bacteriol. 2000, 182, 1507-1514. [CrossRef]

81. Huertas, M.; López-Maury, L.; Giner-Lamia, J.; Riego, A.M.S.; Florencio, F.J. Metals in Cyanobacteria: Analysis of the Copper, Nickel, Cobalt and Arsenic Homeostasis Mechanisms. Life 2014, 4, 865-886. [CrossRef]

82. Daley, S.M.E.; Kappell, A.D.; Carrick, M.J.; Burnap, R.L. Regulation of the Cyanobacterial $\mathrm{CO}_{2}$-Concentrating Mechanism Involves Internal Sensing of NADP+ and $\alpha$-Ketogutarate Levels by Transcription Factor CcmR. PLOS ONE 2012, 7, e41286. [CrossRef]

83. Eisenhut, M.; Huege, J.; Schwarz, D.; Bauwe, H.; Kopka, J.; Hagemann, M. Metabolome Phenotyping of Inorganic Carbon Limitation in Cells of the Wild Type and Photorespiratory Mutants of the Cyanobacterium Synechocystis sp. Strain PCC 6803. Plant Physiol. 2008, 148, 2109-2120. [CrossRef]

84. Figge, R.M.; Cassier-Chauvat, C.; Chauvat, F.; Cerff, R. Characterization and analysis of an NAD $(P) H$ dehydrogenase transcriptional regulator critical for the survival of cyanobacteria facing inorganic carbon starvation and osmotic stress. Mol. Microbiol. 2001, 39, 455-469. [CrossRef]

85. Nishimura, T.; Takahashi, Y.; Yamaguchi, O.; Suzuki, H.; Maeda, S.-I.; Omata, T. Mechanism of low $\mathrm{CO}_{2}$-induced activation of the $\mathrm{cmp}$ bicarbonate transporter operon by a LysR family protein in the cyanobacterium Synechococcus elongatus strain PCC 7942. Mol. Microbiol. 2008, 68, 98-109. [CrossRef] 
86. Takahashi, Y.; Yamaguchi, O.; Omata, T. Roles of CmpR, a LysR family transcriptional regulator, in acclimation of the cyanobacterium Synechococcus sp. strain PCC 7942 to low- $\mathrm{CO}_{2}$ and high-light conditions. Mol. Microbiol. 2004, 52, 837-845. [CrossRef] [PubMed]

87. Tanaka, H.; Kitamura, M.; Nakano, Y.; Katayama, M.; Takahashi, Y.; Kondo, T.; Manabe, K.; Omata, T.; Kutsuna, S. CmpR is Important for Circadian Phasing and Cell Growth. Plant Cell Physiol. 2012, 53, 1561-1569. [CrossRef] [PubMed]

88. Zhang, P.; Sicora, C.I.; Vorontsova, N.; Allahverdiyeva, Y.; Allahverdiyeva, Y.; Nixon, P.J.; Aro, E.-M. FtsH protease is required for induction of inorganic carbon acquisition complexes in Synechocystis sp. PCC 6803. Mol. Microbiol. 2007, 65, 728-740. [CrossRef] [PubMed]

89. Domain, F.; Houot, L.; Chauvat, F.; Cassier-Chauvat, C. Function and regulation of the cyanobacterial genes lexA, recA and ruvB: LexA is critical to the survival of cells facing inorganic carbon starvation. Mol. Microbiol. 2004, 53, 65-80. [CrossRef] [PubMed]

90. Lieman-Hurwitz, J.; Haimovich, M.; Shalev-Malul, G.; Ishii, A.; Hihara, Y.; Gaathon, A.; Lebendiker, M.; Kaplan, A. A cyanobacterial AbrB-like protein affects the apparent photosynthetic affinity for $\mathrm{CO}_{2}$ by modulating low- $\mathrm{CO}_{2}$-induced gene expression. Environ. Microbiol. 2009, 11, 927-936. [CrossRef]

91. Kaniya, Y.; Kizawa, A.; Miyagi, A.; Kawai-Yamada, M.; Uchimiya, H.; Kaneko, Y.; Nishiyama, Y.; Hihara, Y. Deletion of the Transcriptional Regulator cyAbrB2 Deregulates Primary Carbon Metabolism in Synechocystis sp. PCC 68031[W]. Plant Physiol. 2013, 162, 1153-1163. [CrossRef]

92. Orf, I.; Schwarz, D.; Kaplan, A.; Kopka, J.; Hess, W.R.; Hagemann, M.; Klähn, S. CyAbrB2 Contributes to the Transcriptional Regulation of Low $\mathrm{CO}_{2}$ Acclimation in Synechocystis sp. PCC 6803. Plant Cell Physiol. 2016, 57, 2232-2243. [CrossRef]

93. Sjöholm, J.; Oliveira, P.; Lindblad, P. Transcription and Regulation of the Bidirectional Hydrogenase in the Cyanobacterium Nostoc sp. Strain PCC 7120. Appl. Environ. Microbiol. 2007, 73, 5435-5446. [CrossRef]

94. Oliveira, P.; Lindblad, P. Transcriptional regulation of the cyanobacterial bidirectional Hox-hydrogenase. Dalton Trans. 2009, 9990-9996. [CrossRef]

95. Ishii, A.; Hihara, Y. An AbrB-Like Transcriptional Regulator, Sll0822, Is Essential for the Activation of Nitrogen-Regulated Genes in Synechocystis sp. PCC 6803. Plant Physiol. 2008, 148, 660-670. [CrossRef]

96. Agervald, Å.; Baebprasert, W.; Zhang, X.; Incharoensakdi, A.; Lindblad, P.; Stensjö, K. The CyAbrB transcription factor CalA regulates the iron superoxide dismutase in Nostoc sp. strain PCC 7120. Environ. Microbiol. 2010, 12, 2826-2837. [CrossRef] [PubMed]

97. Higo, A.; Nishiyama, E.; Nakamura, K.; Hihara, Y.; Ehira, S. cyAbrB Transcriptional Regulators as Safety Devices To Inhibit Heterocyst Differentiation in Anabaena sp. Strain PCC 7120. J. Bacteriol. 2019, 201. [CrossRef] [PubMed]

98. Tanigawa, R.; Shirokane, M.; Maeda, S.-I.; Omata, T.; Tanaka, K.; Takahashi, H. Transcriptional activation of NtcA-dependent promoters of Synechococcus sp. PCC 7942 by 2-oxoglutarate in vitro. Proc. Natl. Acad. Sci. USA 2002, 99, 4251-4255. [CrossRef]

99. Zhao, M.-X.; Jiang, Y.-L.; He, Y.-X.; Chen, Y.-F.; Teng, Y.-B.; Chen, Y.; Zhang, C.-C.; Zhou, C.-Z. Structural basis for the allosteric control of the global transcription factor NtcA by the nitrogen starvation signal 2-oxoglutarate. Proc. Natl. Acad. Sci. USA 2010, 107, 12487-12492. [CrossRef]

100. Espinosa, J.; Forchhammer, K.; Burillo, S.; Contreras, A. Interaction network in cyanobacterial nitrogen regulation: PipX, a protein that interacts in a 2-oxoglutarate dependent manner with PII and NtcA. Mol. Microbiol. 2006, 61, 457-469. [CrossRef] [PubMed]

101. Ohashi, Y.; Shi, W.; Takatani, N.; Aichi, M.; Maeda, S.-I.; Watanabe, S.; Yoshikawa, H.; Omata, T. Regulation of nitrate assimilation in cyanobacteria. J. Exp. Bot. 2011, 62, 1411-1424. [CrossRef]

102. Su, Z.; Olman, V.; Mao, F.; Xu, Y. Comparative genomics analysis of NtcA regulons in cyanobacteria: Regulation of nitrogen assimilation and its coupling to photosynthesis. Nucleic Acids Res. 2005, 33, 5156-5171. [CrossRef]

103. Mitschke, J.; Vioque, A.; Haas, F.; Hess, W.R.; Muro-Pastor, A.M. Dynamics of transcriptional start site selection during nitrogen stress-induced cell differentiation in Anabaena sp. PCC7120. Proc. Natl. Acad. Sci. USA 2011, 108, 20130-20135. [CrossRef]

104. Galmozzi, C.V.; Saelices, L.; Florencio, F.J.; Muro-Pastor, M.I. Posttranscriptional Regulation of Glutamine Synthetase in the Filamentous Cyanobacterium Anabaena sp. PCC 7120: Differential Expression between Vegetative Cells and Heterocysts. J. Bacteriol. 2010, 192, 4701-4711. [CrossRef] 
105. Kang, R.-J.; Shi, D.-J.; Cong, W.; Cai, Z.-L.; Ouyang, F. Regulation of $\mathrm{CO}_{2}$ on heterocyst differentiation and nitrate uptake in the cyanobacterium Anabaena sp. PCC 7120. J. Appl. Microbiol. 2005, 98, 693-698. [CrossRef]

106. Flores, E.; Arévalo, S.; Burnat, M. Cyanophycin and arginine metabolism in cyanobacteria. Algal Res. 2019, 42, 101577. [CrossRef]

107. Lopez-Gomollon, S.; Hernández, J.A.; Pellicer, S.; Angarica, V.E.; Peleato, M.L.; Fillat, M.F. Cross-talk Between Iron and Nitrogen Regulatory Networks in Anabaena (Nostoc) sp. PCC 7120: Identification of Overlapping Genes in FurA and NtcA Regulons. J. Mol. Biol. 2007, 374, 267-281. [CrossRef] [PubMed]

108. Raven, J.A.; Evans, M.C.W.; Korb, R.E. The role of trace metals in photosynthetic electron transport in $\mathrm{O}_{2}$-evolving organisms. Photosynth. Res. 1999, 60, 111-150. [CrossRef]

109. Gupta, J.K.; Rai, P.; Jain, K.K.; Srivastava, S. Overexpression of bicarbonate transporters in the marine cyanobacterium Synechococcus sp. PCC 7002 increases growth rate and glycogen accumulation. Biotechnol. Biofuels 2020, 13, 17. [CrossRef] [PubMed]

110. Cano, M.; Holland, S.C.; Artier, J.; Burnap, R.L.; Ghirardi, M.; Morgan, J.A.; Yu, J. Glycogen Synthesis and Metabolite Overflow Contribute to Energy Balancing in Cyanobacteria. Cell Rep. 2018, 23, 667-672. [CrossRef]

111. Schwarz, D.; Orf, I.; Kopka, J.; Hagemann, M. Effects of Inorganic Carbon Limitation on the Metabolome of the Synechocystis sp. PCC 6803 Mutant Defective in glnB Encoding the Central Regulator PII of Cyanobacterial C/N Acclimation. Metabolites 2014, 4, 232-247. [CrossRef]

112. Vermaas, W.F. Photosynthesis and Respiration in Cyanobacteria. In Encyclopedia of Life Sciences; John Wiley \& Sons, Ltd.: Chichester, UK, 2001. [CrossRef]

113. Welkie, D.G.; Rubin, B.E.; Diamond, S.; Hood, R.D.; Savage, D.F.; Golden, S.S. A Hard Day's Night: Cyanobacteria in Diel Cycles. Trends Microbiol. 2019, 27, 231-242. [CrossRef]

114. Makowka, A.; Nichelmann, L.; Schulze, D.; Spengler, K.; Wittmann, C.; Forchhammer, K.; Gutekunst, K. Glycolytic Shunts Replenish the Calvin-Benson-Bassham Cycle as Anaplerotic Reactions in Cyanobacteria. Mol. Plant 2020, 13, 471-482. [CrossRef]

115. Huege, J.; Goetze, J.; Schwarz, D.; Bauwe, H.; Hagemann, M.; Kopka, J. Modulation of the Major Paths of Carbon in Photorespiratory Mutants of Synechocystis. PLoS ONE 2011, 6, e16278. [CrossRef]

116. Tang, J.K.-H.; Tang, Y.J.; Blankenship, R.E. Carbon Metabolic Pathways in Phototrophic Bacteria and Their Broader Evolutionary Implications. Front. Microbiol. 2011, 2, 165. [CrossRef]

Publisher's Note: MDPI stays neutral with regard to jurisdictional claims in published maps and institutional affiliations.

(C) 2020 by the authors. Licensee MDPI, Basel, Switzerland. This article is an open access article distributed under the terms and conditions of the Creative Commons Attribution (CC BY) license (http://creativecommons.org/licenses/by/4.0/). 